Article

\title{
Discontinuity Characterization of Rock Masses through Terrestrial Laser Scanner and Unmanned Aerial Vehicle Techniques Aimed at Slope Stability Assessment
}

\author{
Marco Pagano ${ }^{1}$, Biagio Palma ${ }^{1}$, Anna Ruocco ${ }^{1}$ and Mario Parise ${ }^{2,3, *(D)}$ \\ 1 IdroGeo Srl, 80069 Vico Equense, Italy; marcopagano@idrogeo.it (M.P.); palma@idrogeo.it (B.P.); \\ annaruocco@idrogeo.it (A.R.) \\ 2 Earth and Environmental Sciences Department, University Aldo Moro, 70125 Bari, Italy \\ 3 National Research Council, Institute of Research for Geo-Hydrological Protection, 70126 Bari, Italy \\ * Correspondence: mario.parise@uniba.it
}

Received: 25 March 2020; Accepted: 22 April 2020; Published: 24 April 2020

\begin{abstract}
Stabilization projects of rock masses cannot be performed without a proper geomechanical characterization. The classical approaches, due to logistic issues, typically are not able to cover extensively the areas under study. Geo-structural analysis on point cloud from terrestrial laser scanning and photogrammetry from unmanned aerial vehicles are valid tools for analysis of discontinuity systems. Such methodologies provide reliable data even in complex environmental settings (active cliffs) or at inaccessible sites (excavation fronts in tunnels), offering advantages in terms of both safety of the operators and economic and time issues. We present the implementation of these techniques at a tuff cliff over the Santa Caterina beach (Campania) and at the main entrance of Castellana Caves (Apulia). In the first case study, we also perform an integration of the two techniques. Both sites are of significant tourist and economic value, and present instability conditions common to wide areas of southern Italy: namely, retrogressive evolution of active cliffs along the coast, and instability at the rims of natural and/or artificial sinkholes. The results show the reliability of the data obtained through semi-automatic methods to extract the discontinuity sets from the point clouds, and their agreement with data collected in the field through classical approaches. Advantages and drawbacks of the techniques are illustrated and discussed.
\end{abstract}

Keywords: laser scanner; geo-structural classification; rock mass; stability

\section{Introduction}

Rock masses are typically anisotropic, due to presence of a variety of discontinuities of both primary (bedding planes) and secondary (joints, faults) origin. They present therefore significant variations in the geotechnical and mechanical properties, also in reference to their time-dependent behavior. At this goal, the design in different fields of engineering projects generally considers the use of geotechnical models to characterize a site [1-13]. In such models, the rock types are subdivided into units that can be considered homogenous based upon their lithology and technical properties. In this way a 2- or 3-D schematic representation is obtained, aimed at providing a basis for forecasting the behavior of the involved materials, but also at understanding the likely interactions between the ground and the engineering works.

In the case of carbonate rock masses, the complexity becomes still higher, due to peculiarity of carbonate rocks, and to the effects of karst processes [14-18]. Networks consisting of karst conduits and passages are able to significantly change the behavior of the rock mass; as a matter of fact, 
they are typically the discontinuity sets of greater size and frequency, at the same time showing high pervasiveness throughout the rock mass. This results also in controlling the water flow, which occurs in particular during the most significant rainstorm events. From all these considerations, it appears that karst features strongly complicate any analysis dealing with fractured and karstified carbonate rock masses. Nevertheless, this complication is generally not considered at all in the classical geo-mechanical approaches [19], that are implemented disregarding these important aspects. Karst is known as a particularly difficult to examine environment, so that planning and designing engineering works should be performed with extreme care, including as much as possible the knowledge of the surficial and subterranean karst features, also obtained through direct speleological research and exploration [20-23].

It therefore appears that, whatever the setting and the lithologies involved, the issue of discontinuity analysis within rock masses is crucial for a correct evaluation of the rock stability, as well as for choosing the most suitable stabilization measures.

Standard traditional methods for the geo-mechanical characterization of rock masses are typically time-consuming, with the measurements being confined to some sectors in the rock face, due to difficulties in accessibility [24-27]. Such limitations result in providing only punctual information about the geo-mechanical setting of the rock mass. The main relevant problem for analysis of rock slopes is therefore logistics, and the possibility to directly approach the rock face: since instability processes mostly affect near vertical to vertical slopes, the only opportunity for operators is making a scanline at the base of the cliff, thus strongly limiting the assessment of the overall rock face. Changes in the properties along the rock face, at different heights, are typically estimated through rough, qualitative approaches. As an alternative, availability by rock-climber geologists allows to fill some gaps, representing however a very difficult, expensive, and time-consuming phase of the survey, in any case able to cover only a few vertical lines.

Stereo-photogrammetric techniques are nowadays frequently being used to measure the orientations of discontinuities [28-30]. Adoption of the basic principles of photogrammetry can in fact result extremely useful in rock mechanics and in the evaluation of rock stability as well. The first attempts in this direction, however, were quite frustrating due to the long time required to precisely outline the discontinuities, and the slowness in their elaboration [31-36]. Only during the recent decades, thanks to availability of powerful computers, and advancement in the technologies, these techniques have become widespread, and several approaches have been proposed to obtain 3D models of rock faces by remote sensing data. Among these, terrestrial laser scanners (TLS) and unmanned aerial vehicles (UAV) have undoubtedly proved to be among the most efficient and reliable tools, and are being today used in many stability analyses worldwide [37-50].

In this paper, we present some considerations about the use of surveys from these techniques, through production of dense point clouds and the related semi-automatic acquisition of discontinuity data for stability analysis, based upon some experiences carried out in the last years. Advantages and drawbacks of the single techniques, and of their integration as well, will be illustrated through two significant case studies in southern Italy, concerning a cliff in pyroclastic rocks in Campania and a natural karst cave in Apulia. Choice of the sites was dictated by two common situations in southern Italy, that is instability problems along high sea cliffs and the possibility of failures from natural or artificial sinkholes. This latter case, in detail, was selected to highlight the importance of high-resolution analysis and studies in carbonate rock masses, and the need to include in the analysis the role played by karst processes, which very often is underestimated or neglected. After introductory sections describing the techniques and the instruments used, the two case studies are presented, before reaching the conclusions where our considerations about pros and cons of the techniques are illustrated. 


\section{Materials and Methods}

\subsection{Survey through Laser Scanner 3D}

3D terrestrial laser scanner (TLS) is an innovative methodology to model and monitor rock cliffs and underground environments. The method allows to survey and reproduce the measured surfaces with an acquisition mesh at sub-centimeter resolution. The outcome is a snapshot of the observed scene at the date of acquisition, expressed by millions of georeferenced points; it is easily navigable and shareable through cloud-computing.

The first phase of the survey consists of a careful and detailed analysis of the area, and in the selection of the scan positions, that is the sites where the instrument has to be located; further, based upon the distance between the laser and the object, the resolution of the scan is defined, taking into account the detail required in the output (in turn, depending upon the aim of the work). This activity is mandatory to the survey design, aimed at locating the control points (targets). To reach the best results in terms of final outcome, it is necessary that the scan positions are such that the laser beam is always perpendicular to the main discontinuity sets. In this way, it is possible to have a complete and homogeneous point cloud, without void spaces, and where all the planes of the scanned object could be perfectly recognized when varying the orientation of the model in space.

The survey, carried out in the case studies of this work with a Laser Scanner RIEGL VZ400 (Figure 1), allows acquisition of a georeferenced point cloud of millions of points, each one of which is described by the following information: geographical position in space (X, Y, Z), chromatic information (RGB), and reflectance (i).

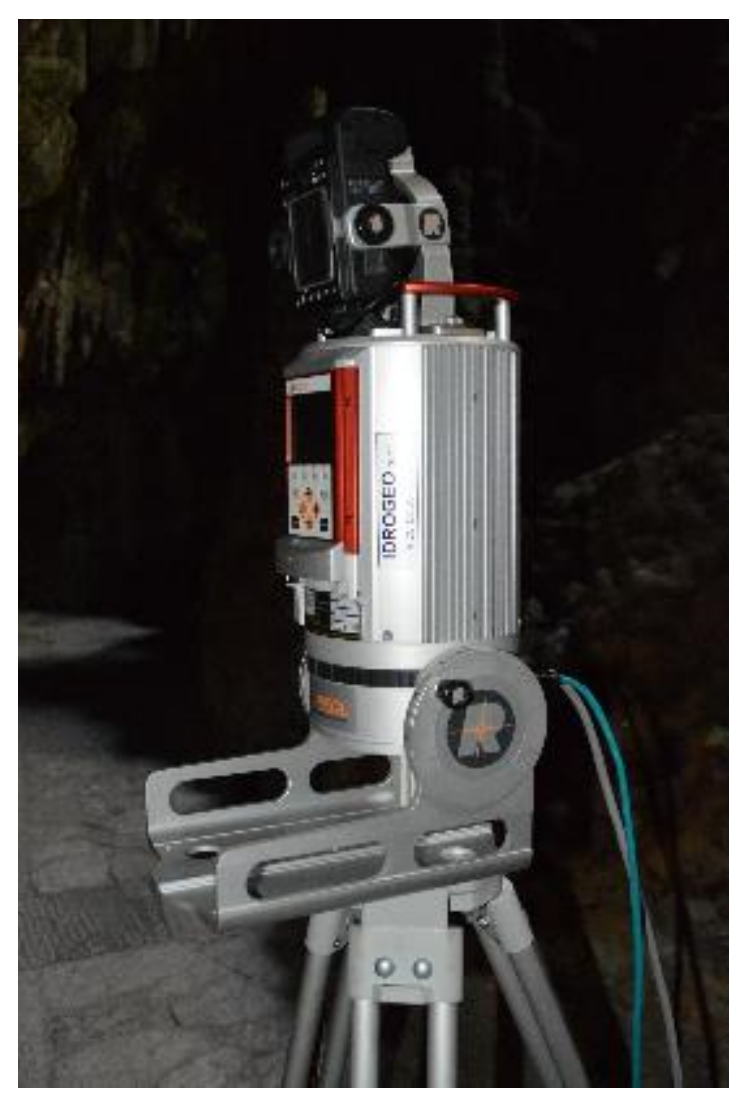

- Class 1 Laser

- Range greater than $500 \mathrm{mt}$

- High definition camera (>6 Mpixel)

- First and last impulse

- Ability to reduce the shadow areas due to vegetation

- Integrated inclinometer sensor and lead laser

- Integrated GPS antenna

- High velocity of acquisition: $\mathrm{min} .122,000 \mathrm{pti} / \mathrm{sec}$

- Scan angles: $360^{\circ}$ horizontal $-360^{\circ}$ vertical

- Precision: $3 \mathrm{~mm}$

- Integrated compass

Figure 1. Main characteristics of the Laser Scanner Riegl VZ400.

During the survey, multiple scans are taken at each scan position, with variable resolution: initially, an overall scan with wide mesh is obtained to get a file that is easy to manage, and to have an immediate control of the wide surveyed area; then, several other scans are produced with progressively more 
accurate meshes. During the phase of setting the detailed scans, the data regarding photographs are set too, that include the exposition time and the diaphragm aperture, so that the digital images to be linked to the point cloud are properly calibrated, based upon the variable light conditions and the closeness to the survey object.

At the end of each scan, before changing the scan position, a detailed scan of the targets is carried out to allow the scanner to localize and record the installed reflectors, which will be used as tie points and ground control points in merging and georeferencing the point cloud.

The data acquired with the laser scanner are elaborated with dedicated post-processing software, to merge the scans at the different scan positions, and to clean the model from untrue elements to eventually move toward the 2D and 3D elaborations [51]. The elaboration phase further includes assignment of colors to the point cloud, linking to each $X, Y, Z$ point also the coordinates $R, G, B$, derived from the images acquired during the acquisition phase. This procedure occurs through alignment techniques, both manual and automatic, between the photos and the scans.

At this point, it is possible to move to merging and roto-translation of the several acquired point clouds. This operation is of crucial importance; aimed at obtaining minor errors, it is necessary to merge the cloud points through high-reflectance targets, georeferenced by means of GPS and high-precision total station. At the end of these operations, the error deriving from merging the scans is evaluated. In case the error results to be unacceptable, "forced" alignment techniques, defined multi-station-adjustment (MSA), are applied. During the adjustment phase, it is possible to bypass the coordinates of targets, and to use the coordinates of the filtrated point clouds (polydata), properly created for each scan. The alignment technique MSA is aimed at reducing the error when "common" points belonging to the different polydata are joined.

Once the scans have been merged, and a unique 3D georeferenced and colored model created [52,53], optimization of the point clouds proceeds by eliminating the untrue elements, the overlapping and redundant points, and the not relevant features (electric cables, etc.), and to reduce the noise [54-56]. The outcome, at this point of the elaboration, is a 3D model consisting of a highly detailed point cloud, able to represent with high accuracy the object geometry.

To provide easier management of the successive phases of implementation, a spatial decimation around the points is carried out, to lighten the data and make them exportable to other software and in other formats.

The final phase of processing the point clouds consists in the realization of the solid surface called mesh, through the software MeshLab, that represents, in an exhaustive manner, the poligonalization of the point cloud to create filled surfaces and volumes of easier visual and computational interpretation.

All the survey products eventually end up in 2D and 3D graphic elaborates such as maps, drawings, profiles, mesh, DTM (digital terrain model), DSM (digital surface model), etc.

\subsection{UAV Photogrammetric Survey}

The technique of photogrammetric survey of rock faces by means of unmanned aerial vehicles (UAV) is used to:

- solve the problems related to lack of stable points where to establish the laser scanner (for instance, at the base of a rock cliff);

- integrate the point cloud from laser scanner in those sectors characterized by no data, due to the relative position between laser and rock cliff;

- $\quad$ survey areas not accessible by land (sea cliffs with no or limited beach, islands, etc.).

The photogrammetric survey was carried out for the case studies here presented by using the UAV ITALDRON 4HSEPRO (Figure 2). 


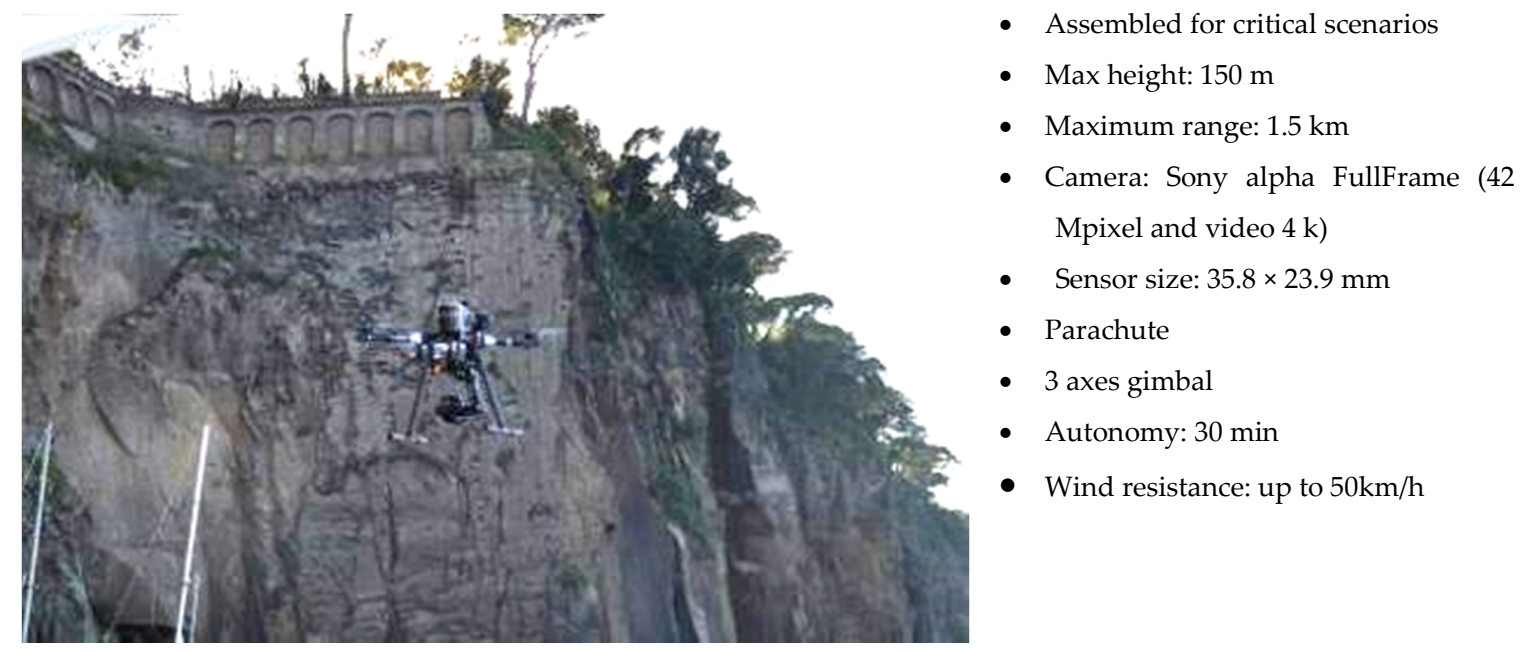

Figure 2. Main features of the Italdron 4HSEPRO.

As a mandatory condition to properly use UAV, there is the need to geo-reference a number of points (ground control points-GCPs) to treat in a metric system the images, and to correctly roto-translate the point cloud. At this goal, we used a GPS (GPS LEICA GS14) and a Total Station (TRIMBLE S6).

Choice of the GCPs must be carefully planned: preferentially, all selected points should be materialized with well-visible targets located in proximity of areas with a chromatic variation, at different elevations, in sectors well distributed over the whole area to be surveyed, far from the shadow areas by trees and other objects.

To increase the quality of the survey, it is preferable to perform a single flight, or, at least, the flight must be carried out in the same part of the day; further, the overlap among adjacent images must never be below $80-85 \%$.

Following the flight, the delicate stage of image elaboration starts, by checking a variety of characteristics, namely:

(1) correct frame of each single snapshot (the optical axis must be perpendicular to the rock face as much as possible);

(2) quality of the image (out of focus photographs must be deleted);

(3) exposure: over- or under-exposed photographs must be deleted, or treated with dedicated software. At this aim, it is better to shoot in raw modality in order to be able to balance the exposure during the post-processing phase;

(4) sequential order of the photograph strips.

Clear pictures with high depth of field are able to provide a good point cloud, whereas a good selection of GCPs allows to reduce significantly the metric errors in the survey. After having properly treated the pictures, the following steps follow (as already described in the previous section for laser scanner surveys, to which readers are referred for details): photographs alignment, building of the dense point cloud, realization of the mesh and of the texturized mesh. These elaborations require the use of commercial software such as Agisoft, Pix4D, ContextCapture, etc.

\section{Geo-Structural Analysis on Point Clouds}

The geo-structural analysis is carried out through innovative methods that allow measurement of the attitude directly on the point clouds. Specific software perform analyses of the point clouds, measuring the values of the normals associated to the identified planes, and how these adapt to aggregates of sets of adjacent points [57,58]. These normals define the orientation of the geometrical bodies to which they belong in space, and are in turn expressed by three spatial coordinates. Thus, 
starting from the point cloud and its DSM (in the case of rock masses coinciding with the DTM), it is necessary to estimate the analytic equations, in the form $\mathrm{AX}+\mathrm{BY}+\mathrm{CZ}+\mathrm{D}=0$ (plane equation), determining orientation and position in the space of the planes that better approximate locally the point cloud.

The most used methods to define and measure these planes are the least squares and the geometric segmentation of DSM [59]. The least squares method takes into account the whole set of available data. However, it is possible that some of the identified planes might aggregate points belonging to different planes, so that the results can be conditioned by gross errors, commonly present when dealing with experimental data. This problem might result in invalidating the overall validity of the model; in other words, there is the risk to have, within the set to interpolate, points belonging to another plane (Figure 3).

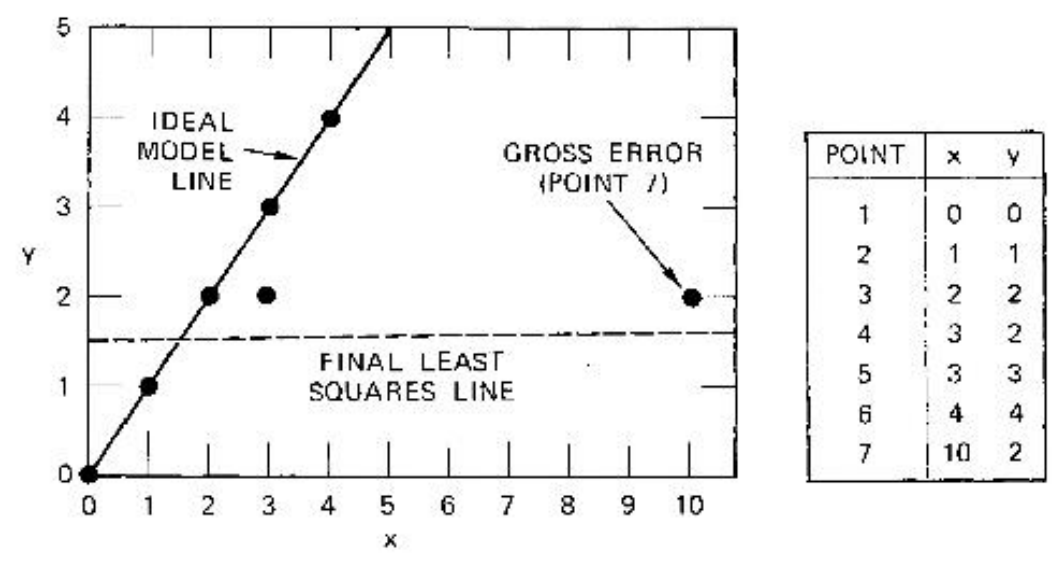

Figure 3. Failure in the reduction to least squares for the estimation of data affected by gross error (after [60]).

The algorithm RANSAC [60,61], on the other hand, allows to identify the different planes and to evaluate the related characteristic equations, also in the presence of a significant percentage of gross errors. The procedure followed by the algorithm is completely different by those in the usual estimation methods: instead of using initially the highest possible number of data to obtain a starting solution, from which to distinguish the invalid points, RANSAC uses the minor possible number of initial data to generate the model, then trying to enlarge such set with data coherent to the model, if possible.

To clarify the procedure, we recall here the bidimensional case of the line to find within a set of experimental data containing a percentage, also significant, of gross errors [62]:

An adequate number of tests is carried out through:

- $\quad$ casual extraction of $n=2$ data (minimum necessary to define the model);

- $\quad$ evaluation of the deviations, with respect to the model: the points that are located within a predefined threshold (green points in Figure 4) are selected, and the others (red points in Figure 4) are discarded.

- $\quad$ The set containing the highest number of data represents the model:

- $\quad$ the selected model is re-estimated at least squares by using all the points classified as inliers. 
a)

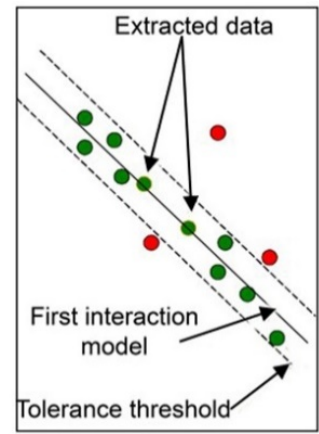

b)



Figure 4. Individuation of the interpolating line in the case of a single dataset (a), and of multiple datasets (b).

Repeating the procedure for $i$ times we will obtain $i$ set of points, each one generated by a different choice of the two initial points. Given a certain value of $i$, it can be stated that with a determined probability $p$ at least one of the couples of initial points does not include an outlier.

In the case more subsets of coherent data are present, the algorithm eliminates all those points belonging to the line that has the highest consensus (in red) and repeats the procedure of researching of the line which best approximates the remaining points (Figure 4; [62]).

At this aim, for each model, tests on different portions of DTM have been carried out to look for a threshold value that is efficient, independently from the average size of portions, roughness and undulation of the wall.

In detail, the present study was realized by using the algorithm Shape Detection of RANSAC (RansacSD) in the form proposed by the University of Bonn [61], that allows to isolate forms, or a set of forms, within the DSM (procedure carried out with the open source software Cloud Compare; CloudCompare Version 2.9.1 User Manual, 2017) [57].

Thus, to extrapolate the planes interpolating aggregates of points with equal attitude, an analysis of the perpendicular associated to the individual planes so determined is performed on the filtrated point cloud; this allows to individuate portions of the space with similar orientation. A new attribute is then assigned to the point cloud by associating the attitude (dip/dip direction) to the perpendicular of each individual plane.

All the points having similar attitude within a defined variability range are selected along the geological alignments of interest, aimed at interpolating the planes that better follow the distribution of the points $[41,63,64]$.

The parameters to be taken into account are [65]:

$>$ maximum number of points belonging to the same plane (function of the point density);

$>$ tolerance threshold of the distance between the selected plane and the other points (function of the point cloud accuracy);

$>$ maximum deviation of the vector normal to the selected plane;

$>$ imposition of threshold values, aimed at finalizing the iterative procedure to look for the most suitable planes, without considering those with greater error. This method is semi-automatic, with manual control and validation, since a process of manual selection of the entities to model is at the origin of a mainly computational phase of recognition, computation and conversion of the normals in geo-structural data, dictated by the experience of the operator who keeps a direct control on the dataset of outcomes.

Eventually, the automatic creation of the discontinuity plane interpolating the selected and near points, and the extraction of the attitude for each of them (computation of dip direction - dip) are obtained. The planes thus individuated by the average parameters of dip and dip direction are represented by means of stereographic projections. The discretization in discontinuity sets is operated 
by means of a selection of the poles of planes through windows within which the value of dip/dip direction is averaged.

\section{Case Studies}

\subsection{Santa Caterina}

The rock cliff over the beach of Santa Caterina is located in the municipality of Sant'Agnello (Naples province, northern coast of the Sorrento Peninsula), in Campania region (Figure 5).

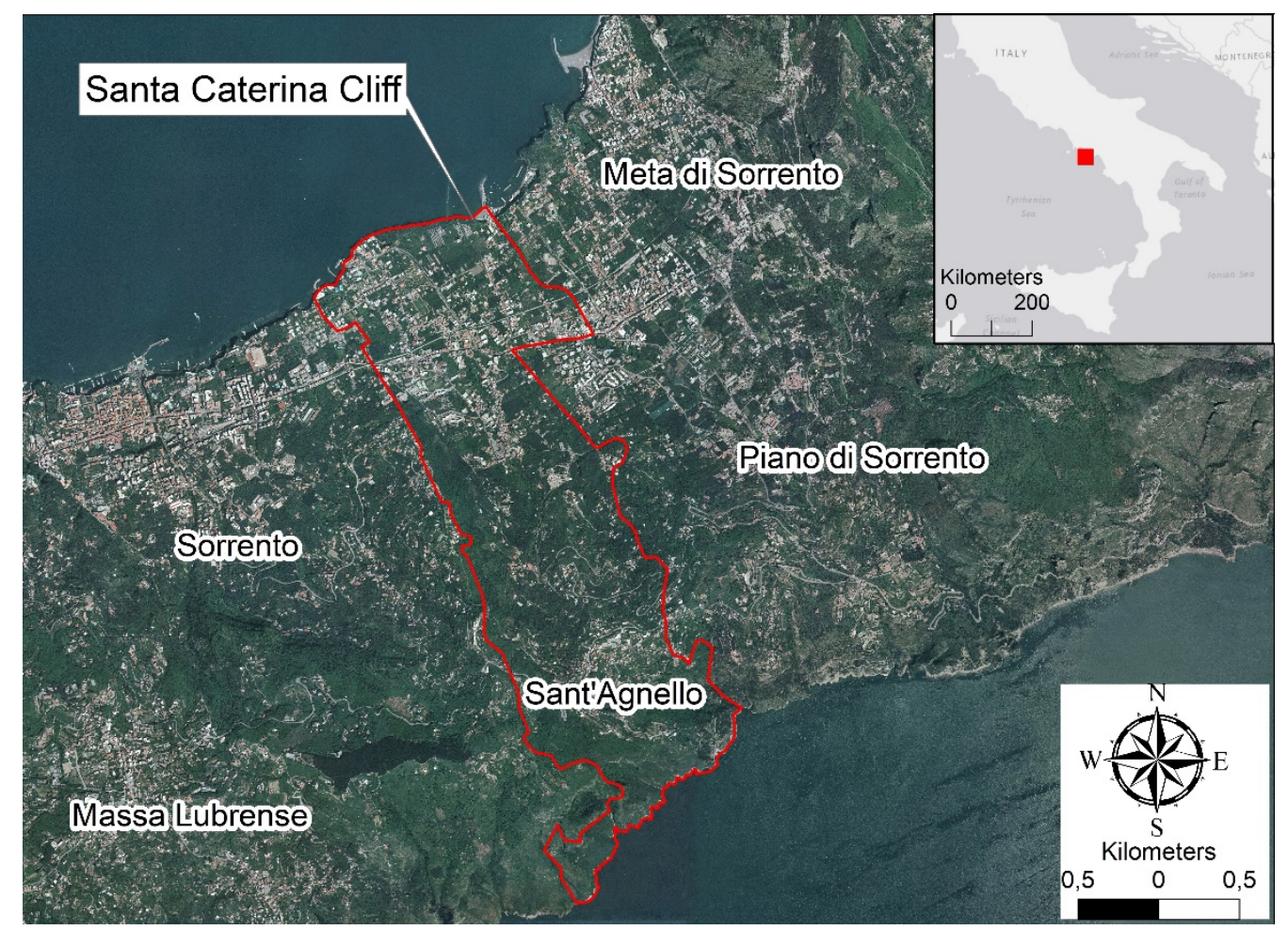

Figure 5. Location of the Santa Caterina cliff, in Campania, southern Italy.

Due to presence of a small marina, and to beauty of the area, which attracts a wide number of tourists during the summer season, the beach is highly frequented.

From a geological-structural standpoint the Sorrento Plain represents a tectonic graben, between two limestone horsts of Cretaceous age. The graben was filled during Wurm with materials from an explosive volcanic eruption, dated about 39,000 years ago [66], within the Phlegrean volcanic district. The volcanic products were emplaced through huge, high temperature, pyroclastic surges and flows, that entirely filled the pre-existing morphologies.

These pyroclastic products belong to the formation of the Campanian Grey Tuff (or Campanian Ignimbrite), consisting of yellow-greyish ashes, associated to black scoriae and lava fragments. After the emplacement, the formation of sanidine and zeolite crystals (zeolitization processes) caused lithification of the pyroclastic material. Cooling processes in the pyroclastic mass generated the development of sub-vertical and strongly inclined joints that, combined with the bedding, create the main discontinuity planes, fragmenting the tuff rock mass. Concerning morphology, the slope is an approximately $50-\mathrm{m}$ high rock cliff, the terrace of pyroclastic aggradation of the Sorrento Plain bounding toward the sea.

The rock cliff shows a retrogressive evolution through rapid slope movements with different failure mechanisms (falls, toppling, slides, wedges). The cliff is directly hit by sea waves, and this action produces a further erosional action, involving both mechanical action and weathering processes $[67,68]$, thus contributing to degrade the rock mass. Eventually, other negative factors working toward 
instability of the cliff are represented by natural factors such as earthquakes, wind, rainfall, and the alteration in the first meters of slope exerted by the tree roots.

Regarding the factors of anthropogenic origin, in the past the rock cliff was interested by quarrying activity to extract the tuff. These activities are testified by presence of artificial cavities and passages, where it is possible to observe a net decrease in the mechanical properties of the rock mass [69-73], with development of release tension cracks and widening in the aperture of the fissures.

In general, the area is characterized by sub-vertical scarps in tuff deposits crossed by multiple discontinuity sets, which intersections determine the formation of isolated, potentially unstable, slabs, wedges, and blocks. Dimensions of the rock blocks are widely variable, from cubic decimeters to cubic meters, in function of the spacing of the main discontinuity sets within the rock mass.

Due to the relevant socio-economical interest of the area and to site logistics, it was decided to proceed with an evaluation of the stability conditions through a geo-structural analysis on point cloud acquired with a combined approach through the use of both laser scanner and drone. Such integrated approach was necessary in order to overcome the logistic and morphological problems present at the site, since the tuff cliff is definitely active, and, as such, not accessible from below for long sectors.

First, a laser survey by means of RIEGL VZ400 was carried out, through acquisition of three scan positions for a total number of 12 scans. Following the preliminary visits to the study area, useful to check the site logistics and its features, including the presence of people and its frequency during the different hours of the day, the survey was planned in order to schedule the best temporal windows, with the aim at avoiding any possible interference. Further, the planning phase included the choice of the precise locations for the control targets. In this specific case, three georeferenced flat targets $(4 \mathrm{~cm}$ diameter plates) and four cylinder targets $(10 \mathrm{~cm}$ diameter) were used.

The laser survey consisted of two phases. The first was carried out during the early morning at the pier located east of the cliff, by performing two scans at $80 \mathrm{~m}$ distance from the cliff, for a temporal duration of $1 \mathrm{~h}$ and $45 \mathrm{~min}$. This procedure allowed to acquire a $2000 \mathrm{pt} / \mathrm{m}^{2}$ point cloud. Then, a third scan was acquired from the beach, $50 \mathrm{~m}$ far from the cliff. This second phase lasted $50 \mathrm{~min}$, and resulted in the acquisition of a point cloud with density of $2000 \mathrm{pt} / \mathrm{m}^{2}$. The two phases of survey allowed to characterize the eastern side only of the cliff.

Then, to get a point cloud adequate to be worked on with geo-structural aims, it should had been necessary to locate the scanner in frontal position with respect to the main discontinuity systems of the rock mass, aimed at avoiding the presence of "dark points" within the point cloud. In the specific case, however, it was not possible to have the scanner in the western sector of the cliff, due to logistic conditions. For this reason, the laser scanner survey was then integrated with a photogrammetric survey by SAPR, carried out by means of the UAV Italdron 4HSE PRO. For this survey, too, the acquisition phase was preceded by inspection visits to investigate the best conditions of light exposition of the cliff, and to establish the strategies to avoid interference with seagulls. The survey was carried out at noon, since this time during the day was the best to guarantee direct light on the cliff, and absence of shadow areas. It was performed in two flights, each one lasting $20 \mathrm{~min}$, to take both frontal and zenithal views of the cliff. The UAV survey, beside covering the western side of the study area (not acquired by the LST survey), overlapped also part of the LST point cloud, eventually resulting in a detailed cloud with density of about $3200 \mathrm{pt} / \mathrm{m}^{2}$.

Regarding this latter survey, to obtain a high-detailed pixel resolution at the ground, needed to perform geo-structural analysis on point clouds, the flight was carried out at maximum distance of $40 \mathrm{~m}$ from the cliff. This allowed to obtain a ground resolution of $5.6 \mathrm{~mm}$ per pixel. During the survey, both zenithal and oblique images were produced, with overlapping percentage always greater than $80-85 \%$. Flight characteristics are as follows:

- $\quad$ Sensor size $35.8 \times 23.9 \mathrm{~mm}$

- Average distance from the cliff: $40 \mathrm{~m}$

- Ground resolution: $5.6 \mathrm{~mm} / \mathrm{px}$

- Overlap H \%: $80 \%$ 
- Overlap L \%: $80 \%$

- Photo height (m): $27.31 \mathrm{~m}$

- Photo width (m): $40.91 \mathrm{~m}$

- Photo spacing (m): $5 \mathrm{~m}$

- Interval (m): $16 \mathrm{~m}$

In order to obtain a high-definition, properly geo-referenced, point cloud (indispensable condition to perform geo-structural analysis on discontinuity of the rock mass), the manual modality of flight was chosen. This was because experience has demonstrated the higher reliability of this modality against the automatic one. It was also decided to acquire photos with high depth of field; therefore, the shoot of the camera was set with ISO priority, keeping blocked both aperture and time during the flight. In addition, the flight direction was chosen according to attitude of the main discontinuities of the rock cliff.

Georeference of real and fake waypoints was carried out. Fake waypoints are represented by a multitude of points within the georeferenced laser-acquired cloud, well identifiable on the screen. This allowed to operate sophisticated roto-translational alignment procedures with the software 3DReshaper, to obtain a cloud at very high resolution, well positioned in space.

In this case study, integrating the point cloud obtained by the laser scanner with that acquired by drone was possible thanks to the very scarce presence of vegetation on the cliff. Actually, when vegetation is present, the photogrammetry by drone is not able to identify the underlying surfaces, differently than the laser scanner equipped with last and first impulse technology, that are capable to partly filtrate the vegetation.

The 3D geometrical model obtained through the combined laser scanner-drone survey produced a high-definition point cloud consisting of 55.6 million points (corresponding to a point density of $\left.6950 \mathrm{pt} / \mathrm{m}^{2}\right), 15.5 \mathrm{million}\left(2000 \mathrm{pt} / \mathrm{m}^{2}\right)$ out of which were from the laser scanner, and $40.1 \mathrm{million}$ $\left(3160 \mathrm{pt} / \mathrm{m}^{2}\right)$ from the drone (Figure 6). This cloud, properly georeferenced with GPS and Total Station, allowed to measure the bedding and spacing of any plane in the rock mass, which is a crucial element for the following phase of designing the stabilization works.

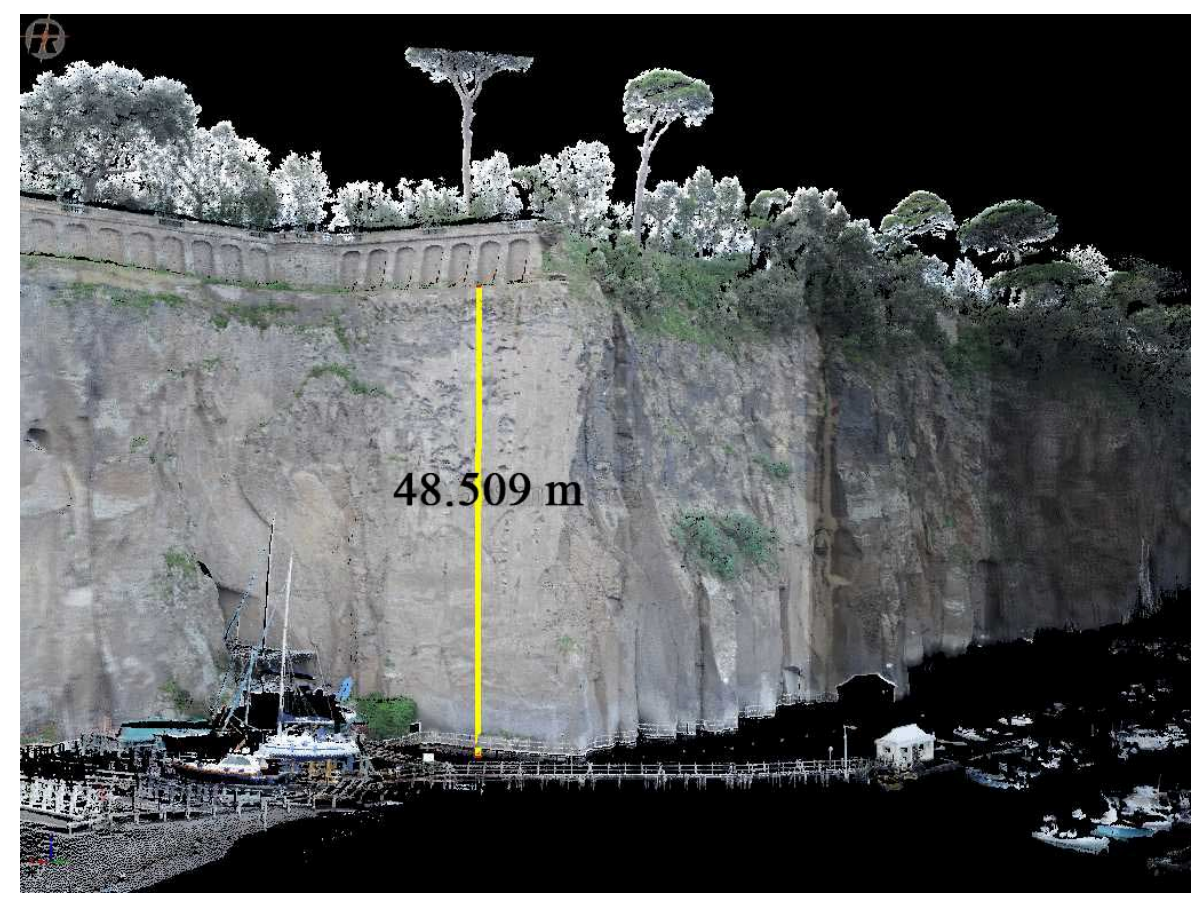

Figure 6. Texturized point cloud at the Santa Caterina cliff. The yellow vertical line provides the height of the cliff. 
The acquired point cloud underwent first a manual procedure of decimation and filtering to eliminate the spurious elements (vegetation, electric cables, trellis, etc.). The cleaned point cloud was then object of a second step of decimation, according to a grid defined in a way to maintain the sections representative of the rock mass. Then, the geo-structural analysis started on the point cloud by individuating portions of space with similar orientation, to extrapolate the value of attitude in terms of dip/dip direction by applying the algorithm RANSAC (Figure 7).
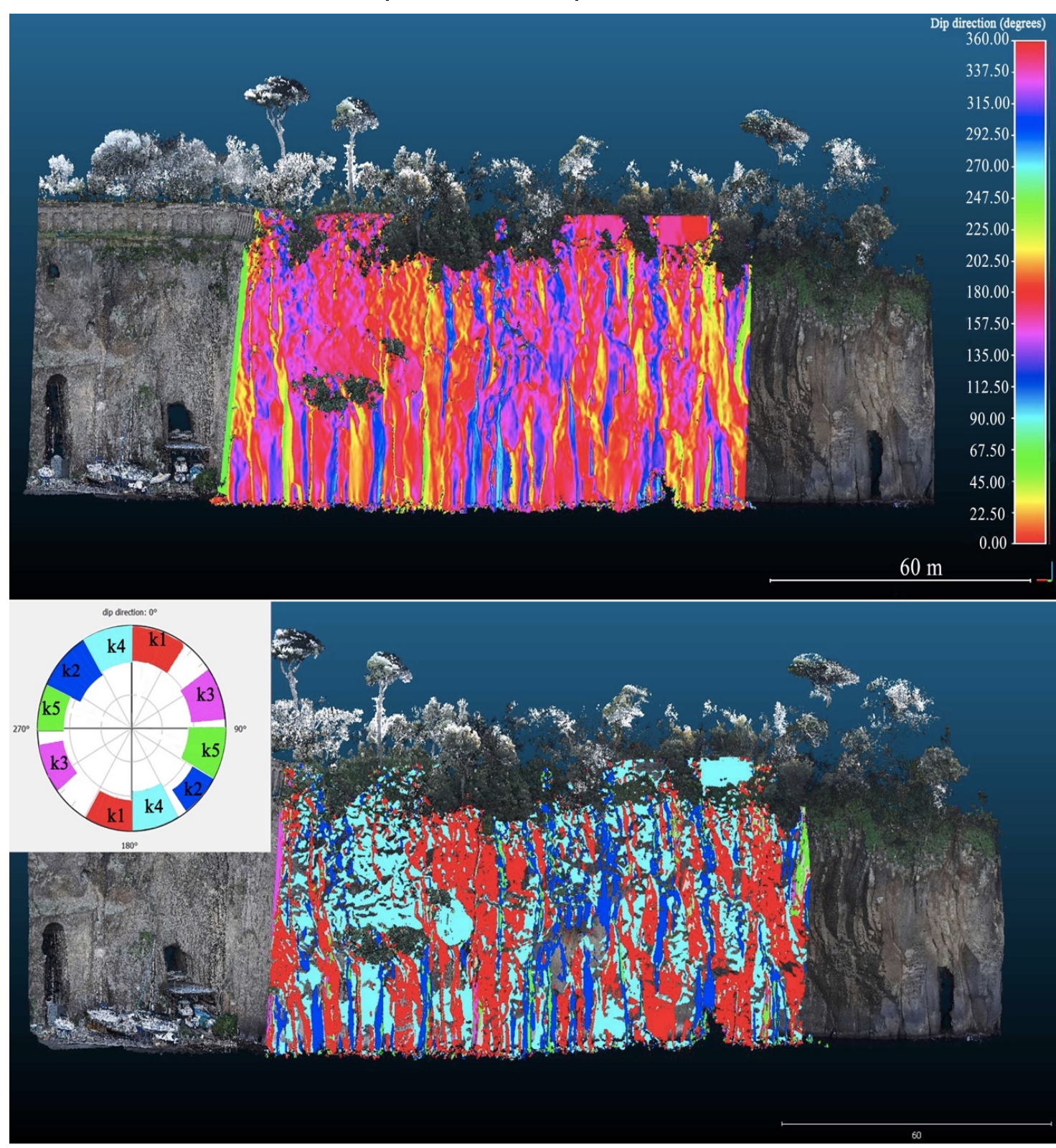

Figure 7. RGB point cloud at Santa Caterina rock cliff. Above: mapping the dip direction value attributed to the point cloud over the study area. Below: representation of the dip directions for each individual discontinuity set, distinguished by different colors; in the inset, the steroplot shows distribution of the sets.

The so identified planes were portrayed on stereonets, and at least five discontinuity sets were detected, summarized in Table 1 and shown in Figure 7. 
Table 1. Average attitude of the discontinuity sets at Santa Caterina rock cliff, identified through geo-structural analysis on point cloud.

\begin{tabular}{lcc}
\hline Set & Dip Direction & Dip \\
\hline K1 & 15 & 77 \\
K2 & 308 & 76 \\
K3 & 72 & 77 \\
K4 & 165 & 75 \\
K5 & 110 & 75 \\
\hline
\end{tabular}

To verify the reliability of the attitudes acquired semi-automatically on the point cloud, some discontinuities in the tuff rock mass were checked on site. In detail, the main discontinuity sets were identified, and traditional measure stations were casually performed by means of the Clar compass. Average attitudes of the main measured discontinuity systems thus obtained are reported in Table 2.

Table 2. Average attitudes of the discontinuity systems identified through geological measurements on the rock mass.

\begin{tabular}{ccc}
\hline Set & Dip Direction & Dip \\
\hline K1 & 17 & 89 \\
K2 & 128 & 88 \\
K3 & 72 & 88 \\
K4 & 345 & 86 \\
\hline
\end{tabular}

The above described procedure allowed to compare the structural data obtained with the two different survey techniques [8], which is the traditional, manual, geomechanical survey, and the geo-structural survey from point cloud acquired with TLS and UAV techniques (Figure 8). Comparing the datasets, it appears that the results obtained from geo-structural survey from point cloud fit well those acquired directly on the rock face.

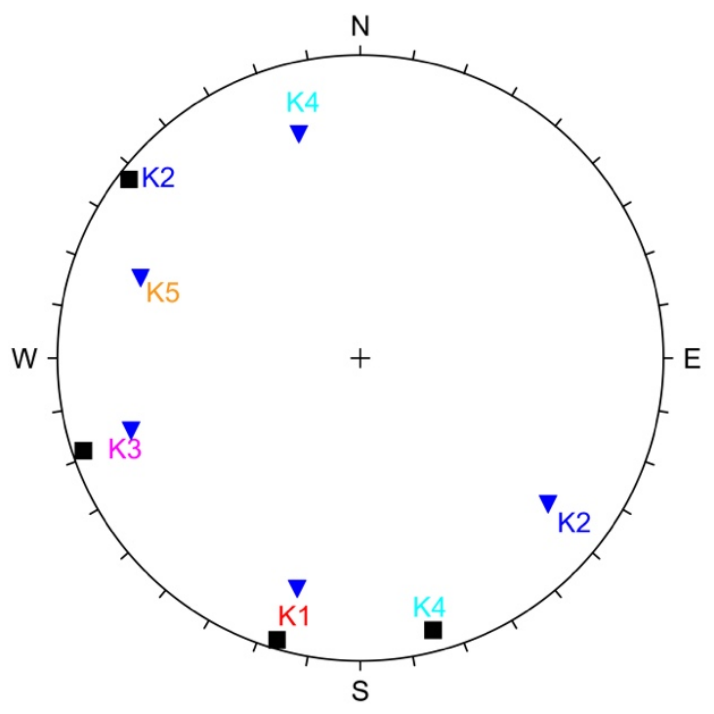

LEGEND

Stereographic poles plot of main discontinuity sets

- by standard manual geomechanical survey

$\boldsymbol{\nabla}$ by geostructural analysis on 3D TLS point cloud

Figure 8. Stereoplot comparing the data from the two different techniques. 
Since the joints show mostly high dipping, variations in the discontinuity polarity are related to the often undulated pattern, which results in opposite sectors within the stereoplot (sets K2 and K4 in Figure 8).

As concerns the K5 set, this was only identified through geo-structural analysis on point cloud. This is because such system is rarely shown in the rock mass, practically consisting of very few joints with high spacing; therefore, the direct acquisitions in correspondence of a limited sector of the rock face, accessible on the ground, did not allow to point out its presence.

\subsection{Castellana Caves}

The Castellana Caves are located in the SE Murge of Apulia (southern Italy; Figure 9), and are one of the most famous Italian karst areas [74-76], with more than 300,000 tourists yearly, as the most visited show cave in Italy. Apulia backbone consists of Jurassic-Cretaceous limestones and dolostones, unconformably overlain Tertiary and Quaternary clastic carbonates, with stratigraphic successions varying in different parts of the region, depending upon paleo-geography of the individual sectors. Since the Lower Pleistocene, Apulia was subjected to a general uplifting, until reaching its present configuration, that is a blocky structure fragmented by high dip faults [77-79]. An extensive network of underground caves and karst conduits, and widespread karst landforms at the surface as well, characterize the three main karst sub-regions (from north to south, Gargano, Murge, and Salento).



Figure 9. Location of the Castellana Caves, in Apulia, southern Italy.

As in other sectors of the Apulian karst, and in many other karst areas worldwide [14,80-88], the development, elongation, and spatial distribution of karst landforms in the Castellana area, both at the surface and underground, is strongly controlled by the main tectonic lineations $[75,89]$.

First explored by Professor Franco Anelli in January 1938, the Castellana Caves were exploited as show cave soon after [90-92], due to beauty of the underground passages and richness in the speleothems decorating the karst systems, whilst in the decades later the explorations added further passages to the overall development, that therefore reached a length greater than $3300 \mathrm{~m}$, with maximum depth of $-122 \mathrm{~m}$ [93]. The karst system has a prevailingly sub-horizontal pattern, with wide caverns 
ranging in height from a few to some tens of meters, and intervening, structurally controlled corridors. The karst system at Castellana opens in the Upper Cretaceous Altamura Limestone formation, showing moderately spaced bedding planes [94]. The carbonate rock mass is fractured, with local arching and deformations in the strata, and thick weathered zones at the contact with clastic sediments or where the carbonates are wetted by trickling or condense water, and weathered material is protected against mechanical erosion [95]. The contact with fine-grained sediments is particularly important, since it contributes to provide the moisture required for dissolution. Corrosive moisture has been in fact invoked as the main reason for limestone weathering in several cases, including the drenching of clay pebble surfaces [96-98].

Besides bedding of strata, showing a sub-horizontal attitude, four main discontinuity systems can be identified at Castellana, the prevailing system always being in the range N 130-150 [99].

The most spectacular view of the system is the $55 \mathrm{~m}$ deep Grave, a natural opening created by a collapse sinkhole $[18,100-103]$, through progressive falls from the vault. The name derives from the pre-Latin term grava, meaning pit or hole, and is locally used to indicate deep entrance to cave systems [104]. This type of feature, generally produced through collapse or cover-collapse sinkhole processes, is very common in the Apulian karst [74,75,105-107]. At Castellana, given the relevance of the Grave (the most iconic symbol of the Castellana Caves, with the typical picture showing the solar ray entering the sinkhole at middle morning), its location above parts of the tourist path, and the need to evaluate the stability conditions, this site was surveyed by means of the laser scanner RIEGL VZ400 (Figure 1).

During the survey, a high-density geo-referenced point cloud (430,000 million points, with $21,500 \mathrm{pt} / \mathrm{m}^{2}$ density) was produced (Figure 10). The survey consisted of 42 scans from 20 scan positions (eight located at the surface, 12 within the cavern). Several different resolution scans were produced at each survey station, and the overall amount of data was processed through dedicated software. In order to obtain frontal scans of the discontinuity sets, seven out of the 12 scans within the Grave were taken with the laser inclined $90^{\circ}$ with respect to the vertical axis, by means of the "Tilt Mounting" tool.

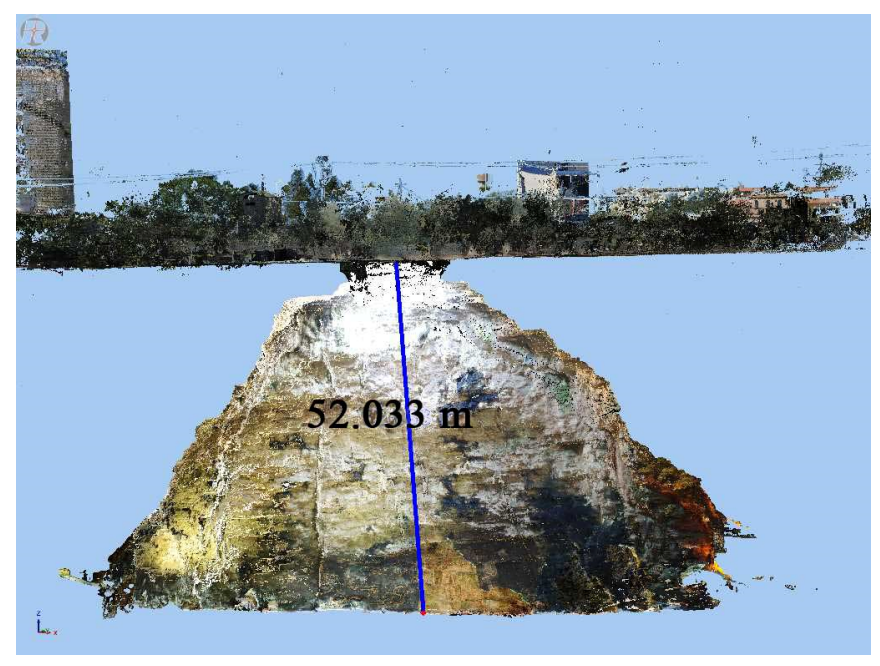

Figure 10. Real numerical model of the point cloud. The blue vertical line provides the height of the cavern.

The resulting point cloud was of high definition, also thanks to presence in the cave of boardwalks and ramps for the tourist visits, that made it possible to locate the scanner at many points. In this way, all the scans were produced at distance not greater than $30-40 \mathrm{~m}$ from the rock walls. Further, the opening of the Grave allowed natural lighting inside the cave, thus obtaining good chromatic 
pictures. At this regard, the survey was carried out during early morning and late afternoon, to avoid the direct arrival of sun rays during the acquisition phase of the photographs.

Overall, the survey required two working days: on the first day, the 10 cylinder targets were surveyed by GPS and total station, and the surface scans outside the cave were performed (16 scans over eight scan-positions), for a total time of $6 \mathrm{~h}$; on the second day, 26 scans within the cavern were carried out in $8 \mathrm{~h}$, also surveying by total station the 15 flat targets. The elaboration process, consisting of linking and roto-translating the different point clouds, and in optimization by cleaning the dataset, produced the high-detail solid surface (mesh) to represent the geometry of the Grave (Figure 11).

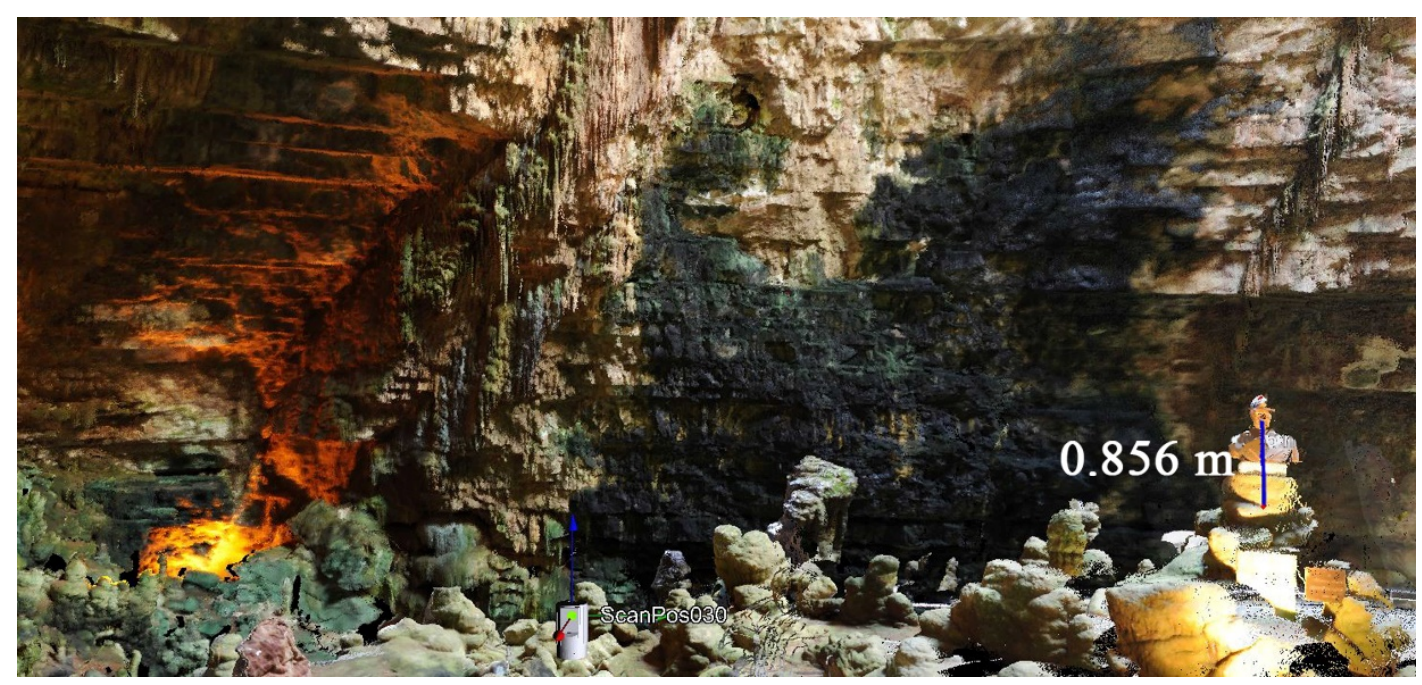

Figure 11. RGB point cloud of the Grave. To the right, height of the bust dedicated to Prof. Franco Anelli (discoverer of the cave system in 1938) provides an indication of scale.

The geological-structural analysis of the Grave was performed by direct measurement of the discontinuity sets in the point cloud through specific software (RiscanPro, Cyclone, Cyclone 3DR, Cloud Compare) able to analyze its attributes, with particular regard to the values (described by three spatial coordinates) of the normals associated to each point within the cloud. The semi-automatic procedure started from identification of sectors showing similar orientation, through analysis of the normals. The same procedure described in the Santa Caterina cliff case study was then followed, assigning a new attribute to the point cloud, computed by associating the attitude (dip/dip direction) to the value of the normal at each point. In this semi-automatic method, the phases of identification, computation, and conversion of the normals in geological datum is preceded by a process of manual selection (control and validation) of the elements to be modelled. This represents a very important point, allowing the operator through his/her expertise to fully control the output.

The planes identified were portrayed in stereographic projections, by ranking the data in sets of discontinuities. The great majority of the attitudes are high dipping; for this reason, variations in discontinuity polarity, due to the possibility to encounter undulated planes, were considered. Three main sets of discontinuities, plus the bedding, were identified from the 113 discontinuity measurements (Table 3). The graphic representation of the main discontinuity planes identified directly from the point cloud is shown in Figure 12. The most frequent and developed sets of tectonic origin (namely, K1 and K2) are well identified by the statistical analysis carried out on the point cloud, as shown by the histogram presented in Figure 13. 
Table 3. Average attitude of the discontinuity sets at Castellana Caves, identified through geo-structural analysis on point cloud.

\begin{tabular}{ccc}
\hline Set & Dip Direction & Dip \\
\hline K1 & 52 & 87 \\
K2 & 151 & 85 \\
K3 & 185 & 85 \\
S' $^{\prime}$ & 212 & 4 \\
S $^{\prime \prime}$ & 35 & 3 \\
\hline
\end{tabular}


Figure 12. Representation of the main discontinuity planes identified directly from the point cloud: (a) all sets; (b) bedding; (c) K1; (d) K2.

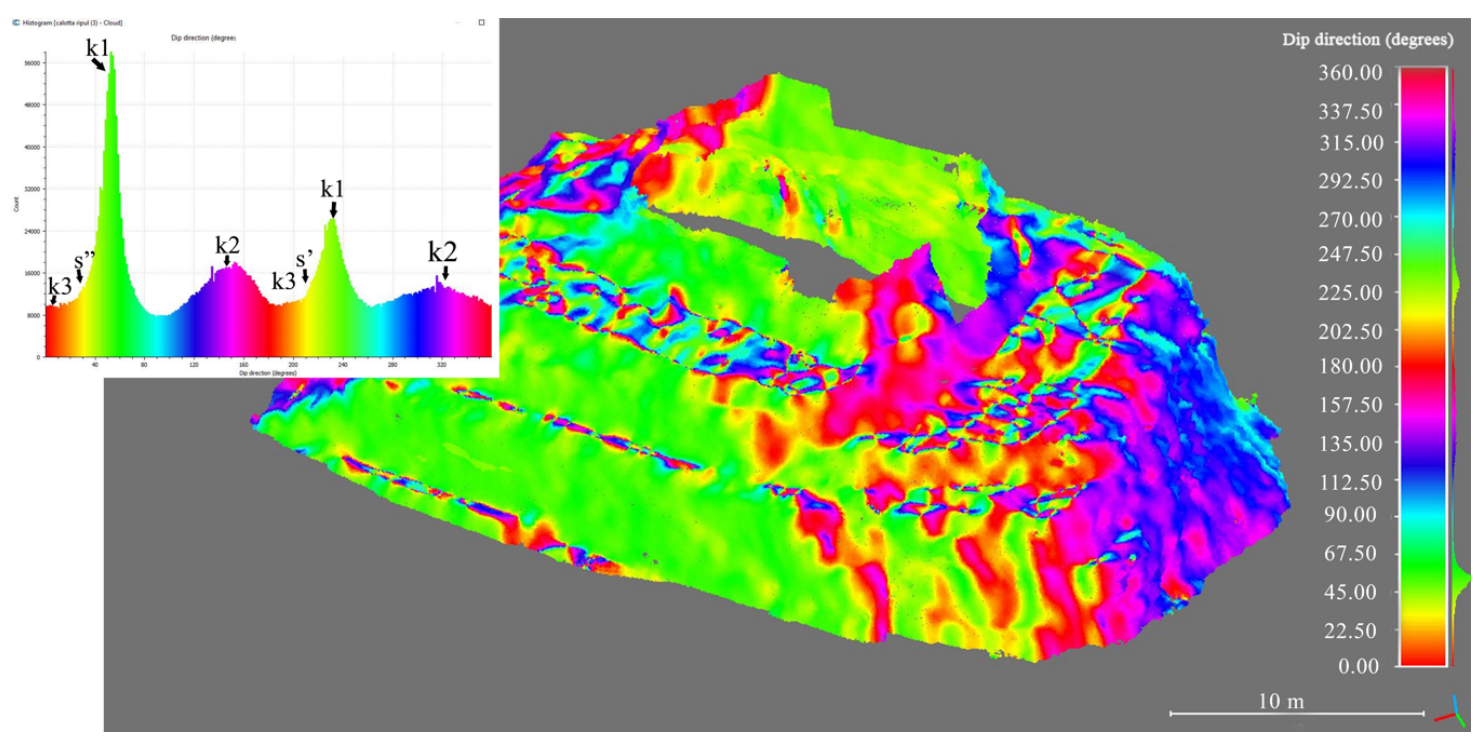

Figure 13. Mapping the dip direction value attributed to the point cloud of the Grave at Castellana Caves. In the inset, the histogram shows distribution of the discontinuity sets, with the most represented clearly corresponding to peaks.

Data obtained through the above described semi-automatic procedure were checked through traditional survey, by operating two scanlines along the vertical walls of the Grave, 
with geologist-climbers (Figure 14) to properly measure the discontinuity parameters. Adopting the recommendations by the International Society for Rock Mechanics [108], all the relevant parameters to describe each discontinuity were measured along the scanlines, in order to fully characterize the sets of discontinuity within the rock mass. The data so acquired (about 50) were portrayed in polar equiareal projection, and analyzed through a cluster analysis. The field data allowed to identify three main sets beside the bedding, plus a few random discontinuities (Table 4).

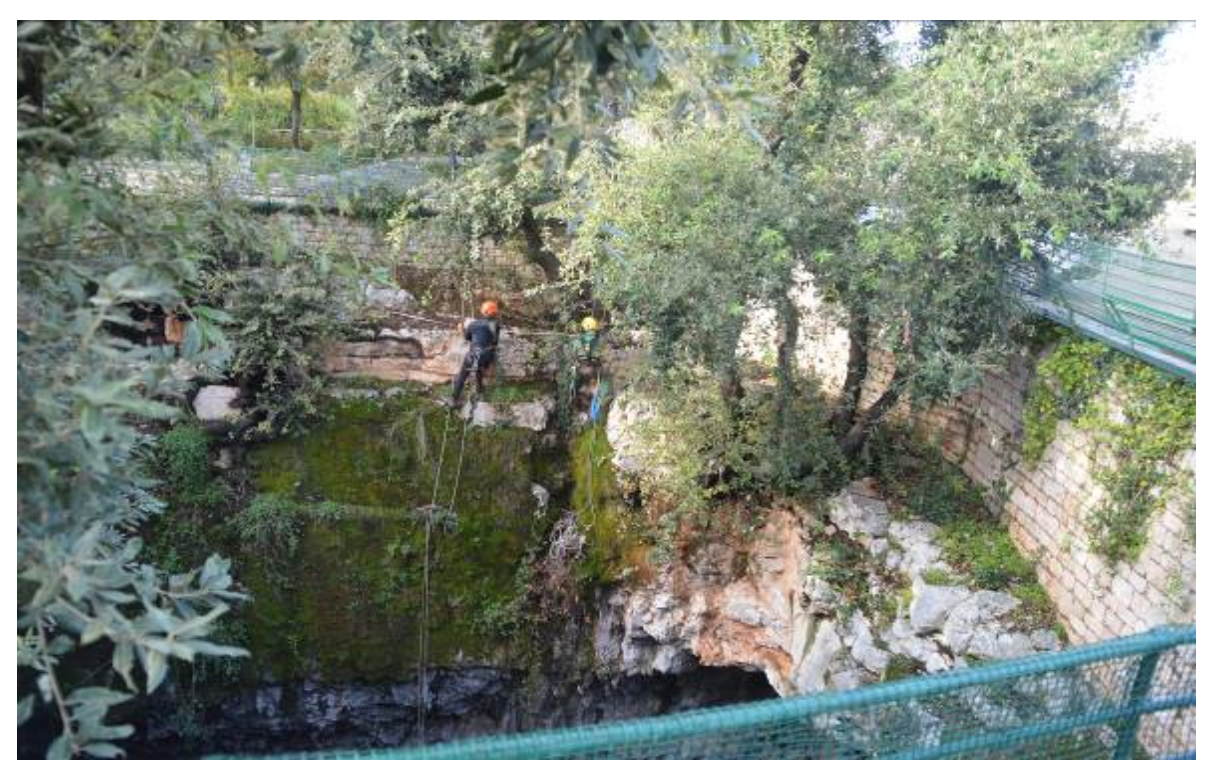

Figure 14. Acquisition phase of geo-mechanical data with standardized techniques (scanline by geologist rock climbers).

Table 4. Average attitude of the discontinuity sets at the Grave entrance, identified by means of the classical geomechanical survey in rock walls.

\begin{tabular}{lcc}
\hline Set & Dip Direction & Dip \\
\hline K1 & 231 & 86 \\
K2 & 309 & 85 \\
K3 & 24 & 87 \\
K4 & 51 & 46 \\
S $^{\prime}$ & 208 & 8 \\
S" $^{\prime \prime}$ & 333 & 6 \\
\hline
\end{tabular}

The data from the traditional geo-mechanical survey were compared with those obtained from the digital survey from cloud point acquired by TLS. The comparison resulted in a good agreement between the different techniques (Figure 15), with slight differences probably related to the logistic difficulties in performing the survey and taking geological measurements along the overhanging sectors of the rock walls. 


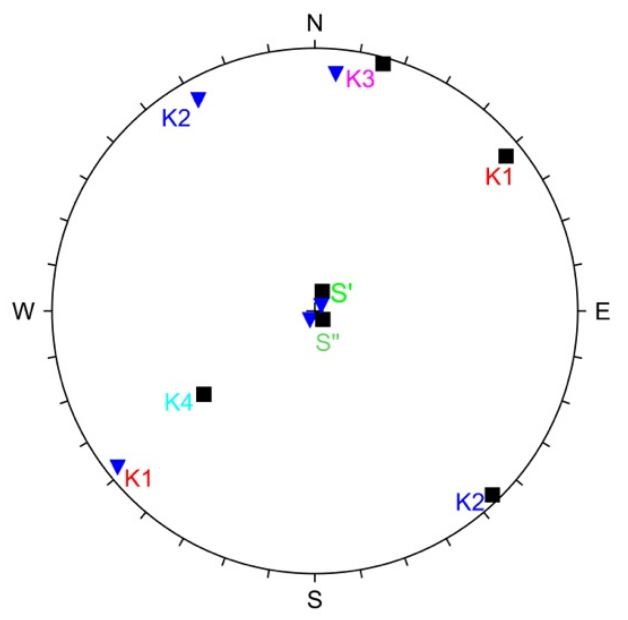

LEGEND

Stereographic poles plot of main discontinuity sets

- by standard manual geomechanical survey

$\boldsymbol{\nabla}$ by geostructural analysis on 3D TLS point cloud

Figure 15. Stereoplot showing the comparison among the data from geo-structural analysis from point cloud and direct acquisition from standard geomechanical survey.

As regards the $\mathrm{K} 4$ set, this is mostly highlighted by lineations at the roof, with scarce presence along the rock mass (walls), and therefore it did not come out from the point cloud geo-structural analysis.

\section{Discussion}

The two case studies presented in this paper regard a very common situation in long stretches of the Italian coastlines (high cliffs interested by rockfalls and slope failures, threatening tourist sites below) and in wide areas of the country where underground voids are present, of both natural (karst caves) or artificial (man-made cavities) origin. Rock failures and sinkholes are definitely among the most significant geological hazards in a fragile territory as Italy. Very often, studying sites affected by these processes has several difficulties related to logistics (overhanging walls, danger from detachment of rocks, etc.) that make it more complicated to carry out a thorough analysis, aimed at defining the kinematics of possible slope movements, at performing the most proper stability analysis, and at designing the related stabilization works.

The traditional approaches to assess the quality of rock masses, as the main available geomechanical classification, proposed since many decades in the international literature [109-117], still appear to be important but present many problems when applied in logistically difficult situations. The fieldwork campaign, necessary for implementation of these classifications, is expensive and time-consuming, and typically does not allow to entirely cover the area under study. Further, it requires somewhat repetitive actions, often resulting in the possibility of having incorrect data.

To effectively reach the goal to evaluate the stability conditions in these situations through detailed analyses, based upon a sound amount of reliable data, the use of remote techniques may play a crucial role in the identification of the discontinuity sets characterizing the rock mass, but need to be carefully planned and always integrated by the necessary geo-structural and geomechanical checks on site $[12,118]$.

We described implementation and integration of techniques used for the above aims, and applied them to study two sites where terrestrial laser scanner and unmanned aerial vehicles were used individually or in combination to build a cloud point from which to develop a semi-automatic extraction of discontinuity data to use for stability analyses. At Santa Caterina cliff, a combination of the two techniques was necessary to ensure a complete coverage of the area under study, at the same time obtaining high quality photographs of the cliff. In the case of Castellana, a variety of scan 
positions to occupy (thanks to the tourist pathways), and good light coming from the outside through the natural opening, permitted to use TLS only.

Through implementation of the two techniques, further integrated by other experience from the literature, and from many years of direct expertise from the authors, we were able to identify the main advantages of these approaches, but also some drawbacks that are worthy of further investigation in the future.

As regards the LST technique, a very positive feature is represented by the high accuracy of the survey (in our case $<5 \mathrm{~mm}$, by using Riegl VZ400), together with the relative velocity in elaboration of the point cloud. On the other hand, drawbacks are the chromatic outcome of photographs, due to the technique used (spherical panchromatic pictures), and the common difficulty in moving around the object to be surveyed, due to site logistics. This latter problem might potentially result in "loosing" some discontinuity sets, depending upon the relative geometries among their attitudes and location of the scan positions.

The two drawbacks above can be solved by using UAV techniques: orthophotos are in this case of good chromatic quality, and there is no problem in moving around the object, which allows to survey the discontinuity plans always with a frontal view. Other problems, however, do still exist, the main one being the presence of "holes" in shadow areas; further, UAV do not typically go through the vegetation, so that in forested areas the percentage of uncovered zones might become significant (this latter drawback being in part common to laser scanner surveys as well). The first problem is not easily solved [119]: even paying attention to the best time during the day for flying, depending upon the light and cliff exposure conditions, there might be sectors of the areas always in the shade (overhanging walls, etc.). A possibility, which however requires longer times, in both acquisition and elaboration phases, is using data from two or more flights, taken at different hours and in different light conditions.

Vegetated areas, on the other hand, can be a real obstacle when it is too dense to obtain an accurate view of the ground. Using Lidar sensors is probably the best way to overcome such drawback.

Other negative aspects about UAV are the impossibility to use it in no-fly zones (densely urbanized areas, landing corridors near airports, military areas, etc.); lower accuracy (1-2 to some $\mathrm{cm}$, depending upon technical features of the camera and distance from the object), also in function of the impossibility to keep a constant distance from the cliff; survey heavily conditioned by the meteoric and climatic conditions (wind, humidity, sun light, etc.); long elaboration times for post-processing, requiring robust and highly performing hardware (most recent generation of i7 processor, $64 \mathrm{~Gb}$ RAM, $6 \mathrm{~Gb}$ dedicated video card).

Given all the above considerations about individual LTS and UAV surveys, we are convinced that integrating the point clouds acquired by UAV to that produced from TLS allows to get a complete 3D cloud: this may eventually include also data difficult to be acquired from fixed measurement positions (a feature typical of TLS acquisitions), such as horizontal terraces, flat roofs of buildings, and areas hidden by obstacles. The integration is also extremely useful in those cases where it is not possible to perform surveys from the land, or to reach the upper sectors of rock faces, and the top of mountains, ridges, and hills, due to complex morphology and topography.

Based upon our experiences, we conclude that:

$>$ Discontinuity analysis by means of remote sensing techniques results in good outcomes through the semi-automatic extraction of data, thus allowing to solve significant logistic problems encountered by the classical survey methods;

> It is possible to perform a geo-structural characterization of the whole area to study, rather than proceeding site per site. This results in a relevant increase in number of data, useful for probabilistic and statistical elaborations;

$>$ The combined procedure allows to provide a large amount of high-resolution data about a variety of parameters that are fundamental for the proper design of stabilization works. Among these, 
in particular, spacing and persistence of the discontinuities are two main key features in the estimation of the block volume;

$>$ Possibility to highlight the most significant sectors of the investigated areas, where to carry out geomechanical scanlines by geologists/rock climbers, in order to directly acquire parameters such as Joint Compressive Strength, filling materials, etc.;

$>$ The combined use of UAV and TLS is recommended wherever the logistics do not allow to establish TLS scan positions at different locations, and, even more, for frontal views toward the discontinuity planes;

$>$ Increase in the safety of the operators working in the field;

$>$ Less time required for data acquisition (this is a very significant, if not strategic, point in settings as tunnels and quarries);

$>$ Significant reduction in the costs.

To effectively reach all the above goals it is crucial to develop a dedicated design of the scan positions, aimed at avoiding as much as possible that some of the discontinuity sets might result hidden from the observation points, and to have the possibility to validate the data by means of direct survey in a limited number of accessible points.

Overall, it is particularly worth pointing out the significance of obtaining reliable geo-structural parameters from remote techniques: in detail, the most robust parameters are represented by attitude, persistence, spacing, and aperture (this latter depending upon the laser scanner used); roughness, on the other hand, definitely represents a still uncertain feature. Further, advantages in reaching higher levels of safety for operators, saving time and costs of work, and allowing coverage of the total area to study represent definitely important goals, which encourage toward integrating different techniques whenever this is possible.

Combination with other techniques, too, might be an option, especially in the case of low budget research projects. For instance, the use of digital cameras at high resolution, or in specific cases of thermal cameras, could add further precious information, especially to cover the aforementioned "holes" from UAV surveys, and to get valuable data about thermal changes due to flowing of water and/or dilation of the rock mass.

Author Contributions: Conceptualization, B.P. and M.P. (Mario Parise); methodology, M.P. (Marco Pagano), B.P., A.R. and M.P. (Mario Parise); software, M.P. (Marco Pagano); validation, M.P. (Marco Pagano) and A.R.; data curation, M.P. (Marco Pagano) and A.R.; writing-original draft preparation, M.P. (Marco Pagano) and A.R.; writing-review and editing, M.P. (Mario Parise); supervision, B.P. All authors have read and agreed to the published version of the manuscript.

Funding: This research received no external funding.

Conflicts of Interest: The authors declare no conflict of interest.

\section{References}

1. Fookes, P.G. Geology for engineers: The geological model, prediction and performance. Q. J. Eng. Geol. 1997, 30, 293-424. [CrossRef]

2. Miroshnikova, L.S. Engineering-Geologic models as an effective method of schematization of rock masses for purposes of hydrotechnical construction. Hydrotechn. Constr. 1999, 33, 603-612. [CrossRef]

3. Barla, G.; Barla, M. Continuum and discontinuum modelling in tunnel engineering. Gallerie Grandi Opere Sotter. 2000, 61, 15-35.

4. Jing, L.; Hudson, J.A. Numerical methods in rock mechanics. Int. J. Rock Min. Sci. 2002, 39, 409-427. [CrossRef]

5. Jing, L. A review of techniques, advances and outstanding issues in numerical modelling for rock mechanics and rock engineering. Int. J. Rock Min. Sci. 2003, 40, 283-353. [CrossRef]

6. Garcia-Jerez, A.; Navarro, M.; Alcali, F.J.; Luzon, F.; Perez-Ruiz, J.A.; Enomoto, T.; Vidal, F.; Ocana, E. Shallow velocity structure using joint inversion of array and $\mathrm{h} / \mathrm{v}$ spectral ratio of ambient noise: The case of Mula town (SE of Spain). Soil Dyn. Earthq. Eng. 2007, 27, 907-919. [CrossRef] 
7. Stavropoulou, M.; Exadaktylos, G.; Saratsis, G. A combined threedimensional geological-geostatistical-numerical model of underground excavations in rock. Rock Mech. Rock Eng. 2007, 40, 213-243. [CrossRef]

8. Palma, B.; Ruocco, A.; Lollino, P.; Parise, M. Analysis of the behaviour of a carbonate rock mass due to tunneling in a karst setting. In The Present and Future of Rock Engineering, Proceedings of the 7th Asian Rock Mechanics Symposium, Seoul, Korea, 15-19 October 2012; Han, K.C., Park, C., Kim, J.D., Jeon, S., Song, J.J., Eds.; Korean Society for Rock Mechanics: Seoul, Korea, 2012; pp. 772-781.

9. Palma, B.; Parise, M.; Reichenbach, P.; Guzzetti, F. Rock-fall hazard assessment along a road in the Sorrento Peninsula, Campania, southern Italy. Nat. Hazards 2012, 61, 187-201. [CrossRef]

10. Lisjak, A.; Grasselli, G. A review of discrete modeling techniques for fracturing processes in discontinuous rock masses. J. Rock Mech. Geotech. Eng. 2014, 6, 301-314. [CrossRef]

11. Andriani, G.F.; Parise, M.; Diprizio, G. Uncertainties in the application of rock mass classification and geomechanical models for engineering design in carbonate rocks. In Engineering Geology for Society and Territory, 5. Urban Geology, Sustainable Planning and Landscape Exploitation; Lollino, G., Manconi, A., Guzzetti, F., Culshaw, M., Bobrowsky, P., Luino, F., Eds.; Springer: Berlin, Germany, 2015; Volume 5, pp. 545-548.

12. Andriani, G.F.; Parise, M. On the applicability of geomechanical models for carbonate rock masses interested by karst processes. Environ. Earth Sci. 2015, 74, 7813-7821. [CrossRef]

13. Parise, M.; Ravbar, N.; Živanovic, V.; Mikszewski, A.; Kresic, N.; Mádl-Szonyi, J.; Kukuric, N. Hazards in Karst and Managing Water Resources Quality. In Karst Aquifers-Characterization and Engineering; Stevanovic, Z., Ed.; Professional Practice in Earth Sciences; Springer: Berlin, Germany, 2015; pp. 601-687.

14. Palmer, A.N. Origin and morphology of limestone caves. Geol. Soc. Am. Bull. 1991, 103, 1-21. [CrossRef]

15. Palmer, A.N. Cave Geology; Cave Books: Dayton, OH, USA, 2007.

16. Waltham, A.C. The engineering classification of karst with respect to the role and influence of caves. Int. J. Speleol. 2002, 31, 19-35. [CrossRef]

17. Ford, D.C.; Williams, P. Karst Hydrogeology and Geomorphology; John Wiley and Sons: Chichester, UK, 2007.

18. Parise, M. Rock failures in karst. In Landslides and Engineered Slopes, Proceedings of the 10th International Symposium on Landslides, Xi'an, China, June 30-4 July 2008; Cheng, Z., Zhang, J., Li, Z., Wu, F., Ho, K., Eds.; Taylor and Francis Group: London, UK, 2008; pp. 275-280.

19. Andriani, G.F.; Parise, M. Applying rock mass classifications to carbonate rocks for engineering purposes with a new approach using the rock engineering system. J. Rock Mech. Geotechn. Eng. 2017, 9, 364-369. [CrossRef]

20. Milanovic, P.T. Geological Engineering in Karst; Zebra: Belgrade, Yugoslavia, 2000; p. 347.

21. Milanovic, P. The environmental impacts of human activities and engineering constructions in karst regions. Episodes 2002, 25, 13-21. [CrossRef] [PubMed]

22. Stevanovic, Z.; Jemcov, I.; Milanovic, S. Management of karst aquifers in Serbia for water supply. Environ. Geol. 2007, 51, 743-748. [CrossRef]

23. Parise, M.; Closson, D.; Gutierrez, F.; Stevanovic, Z. Anticipating and managing engineering problems in the complex karst environment. Environ. Earth Sci. 2015, 74, 7823-7835. [CrossRef]

24. Rosser, N.J.; Petley, D.N.; Lim, M.; Dunning, S.; Allison, R.J. Terrestrial laser scanning for monitoring the process of hard rock coastal cliff erosion. Q. J. Eng. Geol. Hydrogeol. 2005, 38, 363-375. [CrossRef]

25. Oppikofer, T.; Jaboyedoff, M.; Blikra, L.; Derron, M.H.; Metzger, R. Characterization and monitoring of the Åknes rockslide using terrestrial laser scanning. Nat. Hazards Earth Syst. Sci. 2009, 9, 1003-1019. [CrossRef]

26. Viero, A.; Teza, G.; Massironi, M.; Jaboyedoff, M.; Galgaro, A. Laser scanning based recognition of rotational movements on a deep-seated gravitational instability: The Cinque Torri case (North-Eastern Italian Alps). Geomorphology 2010, 122, 191-204. [CrossRef]

27. Riquelme, A.; Tomás, R.; Abellán, A. Characterization of rock slopes through slope mass rating using 3D point clouds. Int. J. Rock Mech. Min. Sci. 2016, 84, 165-176. [CrossRef]

28. Chen, J.; Zhu, H.; Li, X. Automatic extraction of discontinuity orientation from rock mass surface 3D point cloud. Comput. Geosci. 2016, 95, 18-31. [CrossRef]

29. Gomes, R.K.; de Oliveira, L.P.L.; Gonzaga, L.; Tognoli, F.M.W.; Veronez, M.R.; de Souza, M.K. An algorithm for automatic detection and orientation estimation of planar structures in LiDAR-scanned outcrops. Comput. Geosci. 2016, 90, 170-178. [CrossRef] 
30. Riquelme, A.; Cano, M.; Tomás, R.; Abellán, A. Identification of Rock Slope Discontinuity Sets from Laser Scanner and Photogrammetric Point Clouds: A Comparative Analysis. Procedia Eng. 2017, 191, 838-845. [CrossRef]

31. Rengers, N. Terrestrial Photogrammetry: A valuable tool for engineering geological purposes. Rock Mech. Eng. Geol. 1967, 5, 150-154.

32. Feng, Q.; Sjögren, P.; Stephansson, O.; Jing, L. Measuring fracture orientation at exposed rock faces by using a non-reflector total station. Eng. Geol. 2001, 59, 133-146. [CrossRef]

33. Slob, S.; Hack, R. 3D terrestrial laser scanning as a new field measurement and monitoring technique. Lect. Notes Earth Sci. 2004, 104, 179-189.

34. Slob, S.; van Knapen, B.; Hack, R.; Turner, K.; Kemeny, J. Method for automated discontinuity analysis of rock slopes with three-dimensional laser scanning. J. Transp. Res. Board 2005, 1913, 187-194. [CrossRef]

35. Slob, S.; Hack, H.; Feng, Q.; Röshoff, K.; Turner, A. Fracture Mapping using 3D Laser Scanning Techniques. In Proceedings of the 11th Congress of the International Society for Rock Mechanics, Lisbon, Portugal, 9-13 July 2007; pp. 299-302.

36. Abellán, A.; Vilaplana, J.M.; Martínez, J. Application of a long-range terrestrial laser scanner to a detailed rockfall study at Vall de Núria (Eastern Pyrenees, Spain). Eng. Geol. 2006, 88, 136-148. [CrossRef]

37. Sturzenegger, M.; Stead, D. Close-range terrestrial digital photogrammetry and terrestrial laser scanning for discontinuity characterization on rock cuts. Eng. Geol. 2009, 106, 163-182. [CrossRef]

38. Sturzenegger, M.; Stead, D. Quantifying discontinuity orientation and persistence on high mountain rock slopes and large landslides using terrestrial remote sensing techniques. Nat. Hazards Earth Syst. Sci. 2009, 9, 267-287. [CrossRef]

39. García-Sellés, D.; Falivene, O.; Arbués, P.; Gratacos, O.; Tavani, S.; Muñoz, J.A. Supervised identification and reconstruction of near-planar geological surfaces from terrestrial laser scanning. Comput. Geosci. 2011, 37, 1584-1594. [CrossRef]

40. Gigli, G.; Casagli, N. Semi-automatic extraction of rock mass structural data from high resolution LIDAR point clouds. Int. J. Rock Mech. Min. Sci. 2011, 48, 187-198. [CrossRef]

41. Sturzenegger, M.; Stead, D.; Elmo, D. Terrestrial remote sensing-based estimation of mean trace length, trace intensity and block size/shape. Eng. Geol. 2011, 119, 96-111. [CrossRef]

42. Jaboyedoff, M.; Oppikofer, T.; Abellán, A.; Derron, M.H.; Loye, A.; Metzger, R.; Pedrazzini, A. Use of LIDAR in landslide investigations: A review. Nat. Hazards 2012, 61, 5-28. [CrossRef]

43. Brodu, N.; Lague, D. 3D terrestrial lidar data classification of complex natural scenes using a multi-scale dimensionality criterion: Applications in geomorphology. ISPRS J. Photogramm. Remote Sens. 2012, 68, 121-134. [CrossRef]

44. James, M.R.; Robson, S. Straightforward reconstruction of 3D surfaces and topography with a camera: Accuracy and geoscience application. J. Geophys. Res. Earth Surf. 2012, 117, F03017. [CrossRef]

45. James, M.R.; Robson, S. Mitigating systematic error in topographic models derived from UAV and ground-based image networks. Earth Surf. Proc. Landf. 2014, 39, 1413-1420. [CrossRef]

46. Lato, M.J.; Vöge, M. Automated mapping of rock discontinuities in 3D lidar and photogrammetry models. Int. J. Rock Mech. Min. Sci. 2012, 54, 150-158. [CrossRef]

47. Abellán, A.; Oppikofer, T.; Jaboyedoff, M.; Rosser, N.J.; Lim, M.; Lato, M.J. Terrestrial laser scanning of rock slope instabilities. Earth Surf. Proc. Landf. 2014, 39, 80-97. [CrossRef]

48. Abellán, A.; Derron, M.H.; Jaboyedoff, M. 'Use of 3D Point Clouds in Geohazards' Special Issue: Current Challenges and Future Trends. Remote Sens. 2016, 8, 130.

49. Riquelme, A.; Abellán, A.; Tomás, R.; Jaboyedoff, M. A new approach for semi-automatic rock mass joints recognition from 3D point clouds. Comput. Geosci. 2014, 68, 38-52. [CrossRef]

50. Riquelme, A.; Abellán, A.; Tomás, R. Discontinuity spacing analysis in rock masses using 3D point clouds. Eng. Geol. 2015, 195, 185-195. [CrossRef]

51. Lague, D.; Brodu, N.; Leroux, J.J. Accurate 3D comparison of complex topography with terrestrial laser scanner: Application to the Rangitikei canyon (NZ). ISPRS J. Photogramm. Rem. Sens. 2013, 82, 10-26. [CrossRef]

52. Fernández, O. Obtaining a best fitting plane through 3D georeferenced data. J. Struct. Geol. 2005, 27, 855-858. [CrossRef] 
53. Jaboyedoff, M.; Metzger, R.; Oppikofer, T.; Couture, R.; Derron, M.; Locat, J.; Turmel, D. New insight techniques to analyze rock-slope relief using DEM and 3D-imaging cloud points: COLTOP-3D software. In Proceedings of the 1st Canada-US Rock Mechanics Symposium, Vancouver, BC, Canada, 27-31 May 2007.

54. Ester, M.; Kriegel, H.P.; Sander, J.; Xu, X. A density-based algorithm for discovering clusters in large spatial databases with noise. In Proceedings of the Second International Conference on Knowledge Discovery and Data Mining, Portland, OR, USA, 2-4 August 1996; pp. 226-231.

55. Lato, M.; Diederichs, M.S.; Hutchinson, D.J. Bias correction for view-limited Lidar scanning of rock outcrops for structural characterization. Rock Mech. Rock Eng. 2010, 43, 615-628. [CrossRef]

56. Khoshelham, K.; Altundag, D.; Ngan-Tillard, D.; Menenti, M. Influence of range measurement noise on roughness characterization of rock surfaces using terrestrial laser scanning. Int. J. Rock Mech. Min. Sci. 2011, 48, 1215-1223. [CrossRef]

57. Girardeau-Montaut, D. CloudCompare (version 2.8) [GPL Software], OpenSource Project. 2016. Available online: http://www.danielgm.net/cc/ (accessed on 14 November 2019).

58. Dewez, T.J.B.; Girardeau-Montaut, D.; Allanic, C.; Rohmer, J.F. A CloudCompare plugin to extract geological planes from unstructured 3D point clouds. ISPRS Int. Arch. Photogramm. Remote Sens. Spat. Inf. Sci. 2016, XLI-B5, 799-804. [CrossRef]

59. Roncella, R.; Forlani, G.; Remondino, F. Photogrammetry for geological applications: Automatic retrieval of discontinuity orientation in rock slopes. In Proceedings of the International Society for Optics and Photonics, San Diego, CA, USA, 12 May 2004.

60. Fischler, M.A.; Bolles, R.C. Random sample consensus: A paradigm for model fitting with applications to image analysis and automated cartography. Comm. ACM 1981, 24, 381-395. [CrossRef]

61. Schnabel, R.; Wahl, R.; Klein, R. Efficient RANSAC for Point-Cloud Shape Detection. Comput. Graph. Forum Citeseer 2007, 26, 214-226. [CrossRef]

62. Project INTERREG III ALCOTRA; Rockslidetec_Développement d'outils Méthodologiques Pour la Détection et la Propagation des Éboulements de Masse. Final Report. 2002-2006. Available online: http://www.risknat.org/ projets/rockslidetec/ (accessed on 14 November 2019).

63. Olariu, M.I.; Ferguson, J.F.; Aiken, C.L.; Xu, X. Outcrop fracture characterization using terrestrial laser scanners: Deep-water Jackfork sandstone at Big Rock Quarry, Arkansas. Geosphere 2008, 4, 247-259. [CrossRef]

64. Vöge, M.; Lato, M.J.; Diederichs, M.S. Automated rockmass discontinuity mapping from 3-dimensional surface data. Eng. Geol. 2013, 164, 155-162. [CrossRef]

65. Tarsha-Kurdi, F.; Landes, T.; Grussenmeyer, P. Extended RANSAC algorithm for automatic detection of building roof planes from Lidar data. Photogramm. J. Finland 2008, 21, 97-109.

66. De Vivo, B.; Rolandi, G.; Gans, P.B.; Calvert, A.; Bohrson, W.A.; Spera, F.J.; Belkin, A.E. New constraints on the pyroclastic eruption history of the Campanian volcanic plain (Italy). Mineral. Petrol. 2001, 73, 47-65. [CrossRef]

67. Pellegrino, A.; Prestininzi, A.; Scarascia Mugnozza, G. Construction of engineering-geology model of crystalline-metamorphic rock masses experiencing deep weathering processes: Example of application to the Allaro and Amusa river basin (Serre Massif, Calabria, Italy). Ital. J. Eng. Geol. Environ. 2008, 1, $33-60$.

68. Calcaterra, D.; Parise, M. (Eds.) Weathering as a Predisposing Factor to Slope Movements. Geol. Soc. Lond. Eng. Geol. Spec. Publ. 2010, 23, 1-4.

69. Culshaw, M.G.; Waltham, A.C. Natural and artificial cavities as ground engineering hazards. Q. J. Eng. Geol. 1987, 20, 139-150. [CrossRef]

70. Parise, M.; Lollino, P. A preliminary analysis of failure mechanisms in karst and man-made underground caves in Southern Italy. Geomorphology 2011, 134, 132-143. [CrossRef]

71. Del Prete, S.; Parise, M. An overview of the geological and morphological constraints in the excavation of artificial cavities. In Proceedings of the 16th International Congress Speleology, Brno, Czech Republic, 21-28 July 2013; Filippi, M., Bosak, P., Eds.; Czech Speleological Society: Praha, Czech Republic, 2013; Volume 2, pp. 236-241.

72. Lollino, P.; Martimucci, V.; Parise, M. Geological survey and numerical modeling of the potential failure mechanisms of underground caves. Geosys. Eng. 2013, 16, 100-112. [CrossRef]

73. Fazio, N.L.; Perrotti, M.; Lollino, P.; Parise, M.; Vattano, M.; Madonia, G.; Di Maggio, C. A three-dimensional back analysis of the collapse of an underground cavity in soft rocks. Eng. Geol. 2017, 238, 301-311. [CrossRef] 
74. Sauro, U. A polygonal karst in Alte Murge (Puglia, Southern Italy). Z. Geomorph. 1991, 35, 207-223.

75. Parise, M. Surface and subsurface karst geomorphology in the Murge (Apulia, southern Italy). Acta Carsologica 2011, 40, 79-93. [CrossRef]

76. Gueguen, E.; Formicola, W.; Martimucci, M.; Parise, M.; Ragone, G. Geological controls in the development of palaeo-karst systems of High Murge (Apulia). Rend. Online Soc. Geol. Ital. 2012, 21, 617-619.

77. Ricchetti, G.; Ciaranfi, N.; Luperto Sinni, E.; Mongelli, F.; Pieri, P. Geodinamica ed evoluzione sedimentaria e tettonica dell'Avampaese Apulo. Mem. Soc. Geol. Ital. 1988, 41, 57-82.

78. Bosellini, A.; Parente, M. The Apulia Platform margin in the Salento peninsula (southern Italy). Giorn. Geol. 1994, 56, 167-177.

79. Doglioni, C.; Mongelli, F.; Pieri, P. The Puglia uplift (SE Italy): An anomaly in the foreland of the Apenninic subduction due to buckling of a thick continental lithosphere. Tectonics 1994, 13, 1309-1321. [CrossRef]

80. Ford, D.C.; Ewers, R.O. The development of limestone cave systems in the dimensions of length and depth. Can. J. Earth Sci. 1978, 15, 1783-1798. [CrossRef]

81. Palmer, A.N. Patterns of dissolution porosity in carbonate rocks. In Karst Modeling; Palmer, A.N., Palmer, M.V., Sasowsky, I.D., Eds.; Karst Water Institute: Lewisburg, PA, USA, 1999; pp. 71-78.

82. Sebela, S.; Orndorff, R.C.; Weary, D.J. Geological controls in the development of caves in the south-central Ozarks of Missouri, USA. Acta Carsologica 1999, 28, 273-291.

83. Harrison, R.W.; Newell, W.L.; Necdet, M. Karstification along an Active Fault Zone in Cyprus; Kuniansky, E.L., Ed.; Water Res Invest Rep, 02-4174; USGS Karst Interest Group: Atlanta, GA, USA, 2002; pp. 45-48.

84. Klimchouk, A.; Andrejchuk, V. Karst breakdown mechanisms from observations in the gypsum caves of the Western Ukraine: Implications for subsidence hazard assessment. Int. J. Speleol. 2002, 31, 55-88. [CrossRef]

85. Bruno, E.; Calcaterra, D.; Parise, M. Development and morphometry of sinkholes in coastal plains of Apulia, southern Italy. Preliminary sinkhole susceptibility assessment. Eng. Geol. 2008, 99, 198-209. [CrossRef]

86. Iovine, G.; Parise, M.; Trocino, A. Breakdown mechanisms in gypsum caves of southern Italy, and the related effects at the surface. Zeit. Geomorph. 2010, 54 (Suppl. 2), 153-178. [CrossRef]

87. Basso, A.; Bruno, E.; Parise, M.; Pepe, M. Morphometric analysis of sinkholes in a karst coastal area of southern Apulia (Italy). Environ. Earth Sci. 2013, 70, 2545-2559. [CrossRef]

88. Pepe, M.; Parise, M. Structural control on development of karst landscape in the Salento Peninsula (Apulia, SE Italy). Acta Carsologica 2014, 43, 101-114. [CrossRef]

89. De Waele, J.; Parise, M. Discussion on the article "Coastal and inland karst morphologies driven by sea level stands: A GIS based method for their evaluation" by Canora F, Fidelibus D, Spilotro, G. Earth Surf. Proc. Landf. 2013, 38, 902-907. [CrossRef]

90. Anelli, F. First researches of the Italian Institute of Speleology in the Murge of Bari. Le Grotte d'Italia 1938, 2,11-34. (In Italian)

91. Anelli, F. Guide to the excursion II. Bari-Alberobello-Selva di Fasano-Castellana Grotte-Bari. In Proceedings of the XVII Italian Congress Geography, Bari-Salerno, Italy, 23-29 April 1957; pp. 69-120. (In Italian).

92. Parise, M. Some considerations on show cave management issues in Southern Italy. In Karst Management; Van Beynen, P.E., Ed.; Springer: Berlin, Germany, 2011; pp. 159-167.

93. Parise, M.; Proietto, G.; Savino, G.; Tartarelli, M. Ripresa delle attività esplorative alle Grotte di Castellana: Primi risultati e prospettive future. Grotte e Dintorni 2002, 4, 179-186.

94. Lollino, P.; Parise, M.; Reina, A. Numerical analysis of the behavior of a karst cave at Castellana-Grotte, Italy. In Proceedings of the 1st International UDEC Symposium "Numerical Modeling of Discrete Materials", Bochum, Germany, 29 September-1 October 2004; Konietzky, H., Ed.; Taylor and Francis Group: London, UK, 2004; pp. $49-55$.

95. Zupan Hajna, N. Incomplete Solution: Weathering of Cave Walls and the Production, Transport and Deposition of Carbonate Fines. Carsologica, ZRC, Postojna-Ljubljana; Založba ZRC: Ljubljana, Slovenija, 2003.

96. Davis, G.D.; Mosch, C. Pebble indentations: A new speleogen from a Colorado Cave. Bull. Natl. Speleol. Soc. 1988, 50, 17-20.

97. Fookes, P.G.; Hawkins, A.B. Limestone weathering: Its engineering significance and a proposed classification scheme. Quart. J. Eng. Geol. 1988, 21, 7-31. [CrossRef]

98. Waltham, A.C.; Fookes, P.G. Engineering classification of karst ground conditions. Q. J. Eng. Geol. Hydrogeol. 2003, 3, 101-118. [CrossRef] 
99. Parise, M.; Trisciuzzi, M.A. Geomechanical characterization of carbonate rock masses in underground karst systems: A case study from Castellana-Grotte (Italy). In Karst and Cryokarst; Tyc, A., Stefaniak, K., Eds.; Studies of the Faculty of EarthSciences, University of Silesia: Sosnowiec-Wroclaw, Poland, 2007; Volume 45, pp. 227-236.

100. Waltham, T.; Bell, F.; Culshaw, M. Sinkholes and Subsidence; Springer: Chichester, UK, 2005.

101. Parise, M.; Gunn, J. (Eds.) Natural and Anthropogenic Hazards in Karst Areas: Recognition, Analysis and Mitigation; special publication 279; Geological Society: London, UK, 2007.

102. Parise, M. Sinkholes. In Encyclopedia of Caves, 3rd ed.; White, W.B., Culver, D.C., Pipan, T., Eds.; Academic Press, Elsevier: London, UK, 2019; pp. 934-942.

103. Gutierrez, F.; Parise, M.; De Waele, J.; Jourde, H. A review on natural and human-induced geohazards and impacts in karst. Earth-Sci. Rev. 2014, 138, 61-88. [CrossRef]

104. Parise, M.; Federico, A.; Delle Rose, M.; Sammarco, M. Karst terminology in Apulia (southern Italy). Acta Carsologica 2003, 32, 65-82. [CrossRef]

105. Castiglioni, B.; Sauro, U. Large collapse dolines in Puglia (southern Italy): The cases of "Dolina Pozzatina" in the Gargano Plateau and of "Puli" in the Murge. Acta Carsologica 2000, 29, 83-93. [CrossRef]

106. Delle Rose, M.; Federico, A.; Parise, M. Sinkhole genesis and evolution in Apulia, and their interrelations with the anthropogenic environment. Nat. Hazards Earth Syst. Sci. 2004, 4, 747-755. [CrossRef]

107. Simone, O.; Fiore, A. Five large collapse dolines in Apulia (Southern Italy)—The Dolina Pozzatina and the Murgian Puli. Geoheritage 2014, 6, 291-303. [CrossRef]

108. ISRM. Suggested methods for the quantitative description of discontinuities in rock masses. Int. J. Rock Mech. Min. Sci. Geomech. Abs. 1978, 15, 319-368.

109. Barton, N.; Lien, R.; Lunde, J. Engineering classification of rock masses for design of tunnel support. Rock Mech. 1974, 6, 189-236. [CrossRef]

110. Barton, N.; Lien, R.; Lunde, J. Estimation of support requirement for underground excavation. In Proceedings of the 16th US Symposium Rock Mechanics, Minneapolis, MN, USA, 22-24 September 1975; University of Minnesota: Minneapolis, MN, USA, 1975; pp. 163-178.

111. Bieniawski, Z.T. Geomechanics classification of rock masses and its application in tunnelling. In Proceedings of the 3rd International Congress Rock Mechanics, Denver, CO, USA, 1-7 September 1974; Volume 2A, pp. 27-32.

112. Bieniawski, Z.T. Engineering Rock Mass Classifications; John Wiley and Sons: Chichester, UK, 1989.

113. Romana, M. New adjustment ratings for application of Bieniawski classification to slopes. In Proceedings of the International Symposium Role Rock Mechanics, Zacatecas, Mexico, 2-4 September 1985; pp. 49-53.

114. Hoek, E.; Brown, E.T. Practical estimates of rock mass strength. Int. J. Rock Mech. Mining Sci. Geomech. Abs. 1997, 34, 1165-1186. [CrossRef]

115. Hoek, E.; Marinos, P.; Benissi, M. Applicability of the geological strength index (GSI) classification for very weak and sheared rock masses. The case of the Athens Schist Formation. Bull. Eng. Geol. Environ. 1998, 57, 151-160. [CrossRef]

116. Marinos, P.; Hoek, E. Estimating the geotechnical properties of heterogeneous rock masses such as flysch. Bull. Eng. Geol. Environ. 2001, 60, 85-92. [CrossRef]

117. Tomás, R.; Delgado, J.; Serón Ganez, J.B. Modification of slope mass rating (SMR) by continuous functions. Int. J. Rock Mech. Min. Sci. 2007, 44, 1062-1069. [CrossRef]

118. Ferrero, A.M.; Forlani, G.; Roncella, R.; Voyat, H.I. Advanced geostructural survey methods applied to rock mass characterization. Rock Mech. Rock Eng. 2009, 42, 631-665. [CrossRef]

119. Lato, M.; Kemeny, J.; Harrap, R.M.; Bevan, G. Rock bench: Establishing a common repository and standards for assessing rockmass characteristics using LiDAR and photogrammetry. Comput. Geosci. 2013, 50, 106-114. [CrossRef]

(C) 2020 by the authors. Licensee MDPI, Basel, Switzerland. This article is an open access article distributed under the terms and conditions of the Creative Commons Attribution (CC BY) license (http://creativecommons.org/licenses/by/4.0/). 